Article

\title{
A Multi-Analytical Approach to Predict the Determinants of Cloud Computing Adoption in Higher Education Institutions
}

\author{
Yousef A. M. Qasem 1,*, Shahla Asadi ${ }^{1, *}$, Rusli Abdullah 1,*, Yusmadi Yah ${ }^{1}$, Rodziah Atan ${ }^{1}$, \\ Mohammed A. Al-Sharafi ${ }^{2}$ iD and Amr Abdullatif Yassin ${ }^{3}$ (D) \\ 1 Faculty of Computer Science and Information Technology, Universiti Putra Malaysia, Serdang 43400, \\ Malaysia; yusmadi@upm.edu.my (Y.Y.); rodziah@upm.edu.my (R.A.) \\ 2 Faculty of Computer Systems and Software Engineering, University Malaysia Pahang, Kuantan 26600, \\ Malaysia; pcc15013@stdmail.ump.edu.my \\ 3 School of Language Studies and Linguistics, Faculty of Social Sciences and Humanities, \\ Universiti Kebangsaan Malaysia, Bangi 43600, Kajang, Selangor, Malaysia; amryassin84@gmail.com \\ * Correspondence: gs45505@student.upm.edu.my (Y.A.M.Q.); asadi_shahla@upm.edu.my (S.A.); \\ rusli@upm.edu.my (R.A.)
}

Received: 30 May 2020; Accepted: 20 June 2020; Published: 17 July 2020

\begin{abstract}
Cloud computing (CC) delivers services for organizations, particularly for higher education institutions (HEIs) anywhere and anytime, based on scalability and pay-per-use approach. Examining the factors influencing the decision-makers' intention towards adopting CC plays an essential role in HEIs. Therefore, this study aimed to understand and predict the key determinants that drive managerial decision-makers' perspectives for adopting this technology. The data were gathered from 134 institutional managers, involved in the decision making of the institutions. This study applied two analytical approaches, namely variance-based structural equation modeling (i.e., PLS-SEM) and artificial neural network (ANN). First, the PLS-SEM approach has been used for analyzing the proposed model and extracting the significant relationships among the identified factors. The obtained result from PLS-SEM analysis revealed that seven factors were identified as significant in influencing decision-makers' intention towards adopting CC. Second, the normalized importance among those seven significant predictors was ranked utilizing the ANN. The results of the ANN approach showed that technology readiness is the most important predictor for CC adoption, followed by security and competitive pressure. Finally, this study presented a new and innovative approach for comprehending CC adoption, and the results can be used by decision-makers to develop strategies for adopting CC services in their institutions.
\end{abstract}

Keywords: cloud computing; technology adoption; higher education institutions; SEM; neural network

\section{Introduction}

Cloud computing (CC) has emerged as a new technology and popular computing model to deliver access to a huge amount of data and computational resources by utilizing simple interface [1]. There are many characteristics of CC, including flexibility, cost-effectiveness, scalability, and collaboration, which make it crucial for higher education institutes, organizations, and users. According to a CC tracking poll IDC [2], 43\% of HEIs had implemented or sustained CC by 2012. This number increased by 10\% between 2011 and 2012, and the growth is estimated to increase in the next few years. Besides, the International Data Corporation stated that the industrial field, including the education sector, will witness an increase of $\$ 210$ billion or about $23.8 \%$ in the amount of CC by 2019 ; hence, there will be an increase rate of $22.5 \%$ in five consecutive years to become $\$ 370$ billion by 2022 [3]. It has been 
noted that cloud platforms, as well as ecosystems, will function as the launchpad for the drastic rise in the digital innovation pace and scale in the next five years. Additionally, CC is considered to be the fifth utility following the four main utilities, namely water, gas, telephone, and electricity [4]. In the education sector, institutions that provide education to degree-level, tertiary, and HEIs providers [5], will have to keep pace with technological advancement. In the past, investment in IT by these institutions has traditionally been expensive, yet the provided education services to the community are expected to be affordable and maintain excellent quality [6]. To rise to this challenge, HEIs must become more efficient through focusing on the delivery of excellent services, and they need to look for ways to maximize their resources in order to maintain providing excellent services [7]. Although HEIs need to deliver good standards of education through factual knowledge and more practical skills, they have a unique opportunity to graduate skillful and professional students, who are solution-focused and adept at problem-solving [5].

For higher education institutions, CC presents an ideal opportunity to lower their IT costs with increasing efficiency, which has a positive impact on their long-term sustainability. As suggested by Thomas [8], CC is not only a learning tool for HEIs but also an important platform in more general terms as it will encourage educators to improve their practice and encourage partnership in order to improve their productivity. Moreover, CC will be able to save both costs and energy output because the same cloud infrastructure can be utilized by a wide range of users in teaching, learning, and research [9]. Besides, the successful adoption of CC and delivery for cloud-based education services requires understanding of these processes from the side of HEIs [10,11].

Although CC suggests excessive aids to organizations, there are some challenges that might impact its adoption. Several studies on CC have been carried out in developed nations. Studies on CC in educational institutions in developing nations are scarce [12], especially in Malaysia [13,14]. The successful adoption of any novel technology such as CC does not depend only on universities and cloud service providers' support but also on users' willingness and intention to adopt and utilize these services $[12,15,16]$. Therefore, the adoption of any new technology depends on the innovativeness of the decision-makers. That is, the role of decision-makers plays an essential role because they are the main contributors to CC adoption, especially that they can support the required CC services and types in HEIs $[17,18]$.

Many challenges are facing HEIs in sustaining the education process such as delivering affordable education services, improving education quality, increasing budgets and participants, and getting the requirement of infrastructure IT $[19,20]$. Therefore, HEIs keep struggling in managing their resources and improving their service [21]. CC is a favorable solution for HEIs that supports cost reduction and improves education quality [22]. Besides, the sustainability of HEIs can be achieved by providing the required infrastructure, software, and storage through CC adoption $[21,23,24]$. Thus, the emergence of CC and the advantages it provides can help bridge this technological gap. Generally, CC in HEIs is increasing in popularity, but it is still lagging behind the commercial, government, and other sectors [25]. Past literature has shown that productivity at the organizational-level increases significantly for organizations that have invested in ICTs for their operations [26]. Besides, the Coronavirus 2019 (COVID-19) pandemic affected HEIs not just in Wuhan, China where the virus originated but all other HEIs in 188 countries as of 6 April 2020. CC as a technology of the fourth industrial revolution (IR 4.0) could enable educational countermeasures to continue the education process despite the COVID-19 predicaments $[27,28]$. Therefore, CC in this case is not only an alternative option for HEIs but also an essential solution.

In the current study, the unit of analysis is the organization level because the primary focus is on decision-makers, who are responsible for CC adoption. Individuals are considered to be the observers for the phenomenon at the organizational level [29].

Besides, most of the prior studies have primarily focused on CC technology, costs, applications, security, and benefits in small and medium organizations [30]. However, a limited number of studies have focused on CC adoption and its usage in HEIs [3]. Furthermore, several studies have looked at 
CC from different perspectives in various developing countries such as sub-Saharan Africa [30-32], Malaysia [33,34], and Saudi Arabia [18,35,36]. Other studies discussed CC implementation in academic libraries [37,38] and the enhancement of overall awareness regarding CC migration issues [18]. Moreover, organization-based studies have evaluated the readiness of HEIs to implement CCs $[32,39,40]$, and other studies have examined the impacts of technology on HEIs [14,41].

Even though a substantial amount of consideration is given to the $\mathrm{CC}$, few studies have been carried out to identify the influential factors in adopting CC in HEIs from the perspective of decision-makers $[3,30]$. Meanwhile, in spite of the efficiency and usefulness of advanced artificial neural networks (ANN) as a soft computing technique in identifying and ranking determinants in technology adoption [42], application of this technique in the context of CC remains mainly unexplored, especially in education atmosphere. Taking into consideration these points, the current study aimed to develop and test a proposed adoption model and to examine the key factors, influencing decision-makers' intention of CC adoption in Malaysian higher education institutions. Therefore, the key objectives of the current study are as follow:

To analyze the factors that influence the adoption of CC in HEIs.

To propose an appropriate model for evaluating the adoption of CC in HEIs, validated by using two analytical approaches (i.e., PLS-SEM and ANN).

To contribute to the body of knowledge on the organizational-level adoption, this research will first merge two well-established theories which are the Technology-Organizational-Environmental (TOE) framework [43] and the diffusion of innovations (DOI) [44], to fill the gap in previous literature. Drawing on the organizational level adoption theories, our research model is built on the TOE framework and DOI model which is in line with the objectives of this study. Furthermore, the research model constructs are grounded by the literature taking into account the context of the study. The study also implemented variance-based structural equation modeling (PLS-SEM) for assessing the factors impacting CC adoption, and a neural network is used for predicting how CC is adopted in HEIs. For this, the sequential multi-method research design, suggested by Scott and Walczak [45], was implemented as it is suitable for enabling a deeper understanding of the subject under investigation. In this study, PLS-SEM is applied for corroborating the validity of the causal relationships through the assessment of the goodness of the model's fit. Following this, PLS-SEM analysis of supported relationships along with PLS-SEM analysis of significant variables were utilized as the neural network structure inputs for estimating how CC is adopted in HEIs. Merging these two approached provides a significant benefit for utilizing a new method to evaluate CC adoption in which one method benefits help in balancing out the other method drawbacks [45].

Generally, we contribute to research in different ways. First, this research contributes to the body of knowledge within information systems (IS) field surrounding technology adoption. This study provided empirical literature within IS, especially CC, and it provided an extensive model that integrates the TOE framework and DOI model. Second, this study provided an assessment for CC adoption in HEIs, and more revitalization of the CC and intent of decision-makers to utilize CC in HEIs. Third, the DOI model and TOE framework incorporation improved the ability to explain the proposed model with $81 \%$ of the dependent variable's variance, which shows that the model's ability for prediction is powerful and remarkable. Fourth, this research used a hybrid approach for the integration of PLS-SEM and ANN to validate the proposed model and to give priority to the factors that impact CC adoption, through the identification of the relative importance of every factor. Conventional statistical approaches are valid and necessary; thereby, offering a powerful foundation in previous IS adoption studies. The suggestion of this research is the need to reinterpret past works on IS adoption through the combination of linear and non-linear approaches in order to provide outstanding strength to technology adoption. Fifth, since HEI is a promising market for cloud service providers, this study is remarkably impactful for cloud providers and technology practitioners as it will help in the recognition of the factors that influence the adoption of CC. Likewise, cloud providers need to provide a clear instruction or navigation system in guiding users in HEIs to operate the services smoothly, 
thereby increasing the assurance that cloud technology is used. Finally, the research results will help decision-makers with the assessment of cloud technology, organization, and environments during the decision of the adoption of CC. Furthermore, decision-makers may use this proposed framework for the investigation of other IT/IS adoption procedures.

The rest of this study is arranged as follows: Section 2 reviews previous studies on CC adoption. Section 3 presents the hypotheses of the study and discusses the model development. Section 4 highlights the research methodology and Section 5 explains the analytical approaches, including PLS-SEM and neural network. The discussion of the study is presented in Section 6, and Implications are presented in Section 7. Conclusion, limitations, and future research directions are discussed at the end of the study.

\section{Literature Review}

\subsection{Cloud Computing Concept}

The concept of CC does not have a single definition that has been accepted universally as there is still an ongoing discussion and debate about this term. This might be due to some parallels between other types of high-performance computing and CC, such as peer-to-peer computing, cluster computing, market and service-oriented computing, and grid computing [24]. As technology continues to make advancements, the debate around CC continues, and studying the existing literature does reveal some common characteristics for CC across the various available definitions [46].

According to the National Institute of Standards and Technology (NIST), CC is a model that allows wide-ranging, on-demand, network access to shared configurable computing resources such as services, storage, applications, and networks. These resources can be provided quickly and with little effort by either the provider or the customer [47] as they are essentially a way of integrating existing technologies, but provide them in a new way to help businesses make a fundamental change to their operations [48]. This is achieved by connecting existing technology, including software as a service (SaaS), utility computing, and grid computing [49]. Next-generation data centers that combined virtual services such as database, hardware, application logic, and user interface in a network was an objective for the application of cloud technology [50]. Crucially, these new data centers have allowed users to access their applications not only from a singular location but also from any place.

\subsection{Cloud Computing Services and Deployment Models}

According to [47], CC comprises a tripartite of services, infrastructure as a service (IaaS), platform as a service (PaaS) and software as a service (SaaS). The latter enables users to access applications via a cloud-based infrastructure. SaaS means that the infrastructure such as the servers, operating systems, and networks are essentially removed from the consumer, who no longer need to be concerned with this or with other issues such as data storage. To access the services, the customer uses either a direct interface, which is used for web-based emails such as Gmail, or a program interface such as Dropbox. Meanwhile, the IaaS model means that consumers can deploy and run the software, which they choose, through the provision of computing resources such as networks, storage, and processing. This can be achieved through varies softwares, which might be an application or even an entire operating system such as Microsoft Azure and Amazon Web Services, which are two examples of providers within this sphere. Finally, PaaS provides a platform for users to deploy applications on a broader cloud infrastructure and allows them to create and modify their applications by using libraries, services, and languages that have already been developed by a cloud platform provider such as Google App Engine or Heroku.

A description of the four deployment models in cloud technology applications is seen in [47], where these cloud types are named as private, community, public, and hybrid. The private cloud, as the name suggests, is used solely within one organization and its infrastructure may be either self-managed or operated by a third party [51]. This model is usually chosen when security issues are 
a concern for a particular organization, so in the academic sector, this may be due to ownership of certain resources or to cultivate an online community [51].

Concerning the community model, many institutions may use the same basic infrastructure that is hosted either by a third party or by one of the organizations that is part of the community. Organizations may consider this model to be an advantage either through shared costs and resources or because perceived risks are lessened when the model is shared [52]. This model may work well when used by cooperating organizations, or when institutions have a close relationship or are interlinked in some way but can be an issue in higher education sector where many similar institutions are essentially in competition with each other for students, funding and other resources.

The public cloud is probably the most popular form of cloud deployment and is managed by the provider of the service, and the most well-known providers are Microsoft One Drive, Dropbox, and Google Drive as well as those provided by Amazon. In the field of education, users such as students, lecturers and faculty staff will probably be familiar with the system, which is one of its advantages.

The final model of deployment is the hybrid cloud, which combines two or more models. Utilizing more than one model harnesses the benefits of each model and aims to mitigate the disadvantages of every single model as well as to provide a more flexible and wide-ranging approach.

\subsection{Cloud Computing in HEIs}

In the education environment, CC can provide both teachers and students with numerous advantages. Whether in education or research, the ability to store big data and to collaborate on projects and share materials is an attractive proposition [52]. Besides, because CC can be used remotely, users can take advantage of the ability to access these materials on any device at any time and from any place. HEIs and universities have chosen to bypass old-style IT set-ups and software systems in favor of CC, and they have been attracted to its efficiency and rapid implementation [21].

Collaborate approaches to learning are one of the key benefits that CC technology offers, which makes it an ideal choice for the institutions, looking for computer-based technologies to enhance more socially-oriented and cooperative learning styles [53]. Cloud computing also facilitates e-learning in human computing interaction as they are able to utilize facilities such as data access monitoring and storage through a cloud platform, which also provides its infrastructure [54].

Cloud computing is increasing in popularity in HEIs, although it is considered to be in its infancy in this sector of the market, as it is unable to surpass the commercial sector or government organizations [25]. However, it is increasingly becoming a necessary part of the educational offer rather than a choice, and this is due to the increasing competition in the higher education marketplace and the pressures on performance, student successes, and income [55]. HEIs can benefit from the CC features and surpass its limitations so that CC services can be accessible to the practicing educational community [56].

Table 1 illustrates how scientific contributors have discussed this subject from a range of perspectives and how they have attempted to capture the services that CC offers in the higher education sector. Despite this evidence, gaps in research are still clear at the organizational level [57], as many of the existing studies lack empirical findings about CC usage in HEIs [30,31]. This lack of evidence at the organizational level necessitates conducting further studies about CC adoption in HEIs and exploring in depth the factors that affect this process of adoption. Although Table 1 shows the previous literature on adoption of the CC in HEIs that includes the TOE, DOI, and technology acceptance model (TAM) models (TAM1, TAM3), this study is built on the organizational level theories (i.e., TOE and DOI) which is in line with the objectives of the study. 
Table 1. The adoption of CC in HEIs: a summary of prior research studies.

\begin{tabular}{|c|c|c|c|c|}
\hline Study & Title & Theory & Methodology & Country \\
\hline [31] & $\begin{array}{l}\text { "A cross-country model of } \\
\text { contextual factors impacting CC } \\
\text { adoption at universities in } \\
\text { sub-Saharan Africa" }\end{array}$ & $\begin{array}{l}\text { DOI theory and } \\
\text { TAM }\end{array}$ & $\begin{array}{l}\text { Quantitative research. } \\
\text { A survey concerning } \\
\text { university-level ICT experts as } \\
\text { well as decision makers. } \\
355 \text { valid responses. }\end{array}$ & $\begin{array}{l}\text { HEIs in } \\
\text { sub-Saharan Africa }\end{array}$ \\
\hline [30] & $\begin{array}{l}\text { "Conceptualizing a model for } \\
\text { adoption of CC in education" }\end{array}$ & $\begin{array}{l}\text { DOI theory } \\
\text { TAM }\end{array}$ & Conceptual Model & $\begin{array}{l}\text { HEIs in } \\
\text { sub-Saharan Africa }\end{array}$ \\
\hline [58] & $\begin{array}{l}\text { "The Effectiveness of Cloud-Based } \\
\text { E-Learning towards Quality of } \\
\text { Academic Services: An Omanis' } \\
\text { Expert View" }\end{array}$ & N/A & $\begin{array}{l}\text { Qualitative } \\
\text { approach/Semi-structured } \\
\text { interviews. }\end{array}$ & HEIs in Oman. \\
\hline [18] & $\begin{array}{l}\text { "An exploratory study for } \\
\text { investigating the critical success } \\
\text { factors for cloud migration in the } \\
\text { Saudi Arabian higher education } \\
\text { context" }\end{array}$ & $\begin{array}{l}\text { N/A } \\
\text { Success factors } \\
\text { based on literature }\end{array}$ & Structured online questionnaire & $\begin{array}{l}\text { HEIs in Saudi } \\
\text { Arabia }\end{array}$ \\
\hline$[54]$ & $\begin{array}{l}\text { "Using CC for E-learning } \\
\text { systems" }\end{array}$ & LR & & $\begin{array}{l}\text { HEIs in Saudi } \\
\text { Arabia }\end{array}$ \\
\hline$[24]$ & $\begin{array}{l}\text { "Student perceptions of cloud } \\
\text { applications effectiveness in } \\
\text { higher education" }\end{array}$ & N/A & Survey & $\begin{array}{l}\text { University in } \\
\text { Southeast } \\
\text { Michigan USA }\end{array}$ \\
\hline [5] & $\begin{array}{l}\text { "A conceptual model of e-learning } \\
\text { based on CC adoption in higher } \\
\text { education institutions" }\end{array}$ & DOI; FVM & Conceptual Model & HEIs in Oman \\
\hline [59] & $\begin{array}{l}\text { "Examining CC Adoption } \\
\text { Intention in Higher Education: } \\
\text { Exploratory Study" }\end{array}$ & TAM & $\begin{array}{l}\text { A survey utilizing a questionnaire } \\
\text { on paper. }\end{array}$ & $\begin{array}{l}\text { Politehnica } \\
\text { University of } \\
\text { Bucharest, } \\
\text { Romania. }\end{array}$ \\
\hline$[60]$ & $\begin{array}{l}\text { "Investigating the structural } \\
\text { relationship for the determinants } \\
\text { of CC adoption in education" }\end{array}$ & TAM & $\begin{array}{l}\text { A quantitative method/administer } \\
\text { a survey }\end{array}$ & $\begin{array}{l}\text { Universities in } \\
\text { Thailand }\end{array}$ \\
\hline [61] & $\begin{array}{l}\text { "Cloud for e-Learning: } \\
\text { Determinants of Its Adoption by } \\
\text { University Students in a } \\
\text { Developing Country" }\end{array}$ & TAM3 & $\begin{array}{l}\text { An empirical study and a survey } \\
\text { questionnaire }\end{array}$ & Saudi Arabia \\
\hline [62] & $\begin{array}{l}\text { "Determinants and their causal } \\
\text { relationships affecting the } \\
\text { adoption of CC in science and } \\
\text { technology institutions" }\end{array}$ & DOI & $\begin{array}{l}\text { Focus group discussion and } \\
\text { DEMATEL }\end{array}$ & $\begin{array}{l}\text { Science and } \\
\text { technology } \\
\text { institutions, } \\
\text { Taiwan }\end{array}$ \\
\hline [35] & $\begin{array}{l}\text { "CC adoption by HEIs in Saudi } \\
\text { Arabia: an exploratory study" }\end{array}$ & TOE & Survey & $\begin{array}{l}\text { HEIs in Saudi } \\
\text { Arabia }\end{array}$ \\
\hline [63] & $\begin{array}{l}\text { "CC adoption and usage in } \\
\text { community colleges" }\end{array}$ & TAM3 & $\begin{array}{l}\text { Virtual Computing Lab and focus } \\
\text { groups concerning instructors as } \\
\text { well as interviews of other } \\
\text { stakeholders such as IT support } \\
\text { staff and college administrators }\end{array}$ & $\begin{array}{l}\text { Rural and urban } \\
\text { community } \\
\text { colleges, USA }\end{array}$ \\
\hline
\end{tabular}

\subsection{Technology Adoption Theories}

The adoption process refers to the decision-making individual (the adopter) or unit undergoing the process of taking a new product, service, or idea into account [44]. There are numerous phases involved in this process, and the outcome is the decision of whether the new item should be selected. According to [64], the decision is made by an entity regarding the adoption of a particular object and in a specific context. Moreover, various factors are affecting this decision, and in the present study, HEI is the entity while CC adoption is the object. After analyzing previous studies, it was found that many studies considered constructs influencing the CC adoption at an individual level ([24,59-61,63,65-77]); however, there was a dearth of material concerning this at the organizational level [31,32,35]. As mentioned above, the two most dominant hypotheses used for considering technology adoption from an organizational perspective are the TOE framework, and the DOI model [31,32,35,78-84]. 


\subsubsection{TOE Framework}

TOE framework can define the innovation process within an enterprise context because TOE considers three aspects of an enterprise, namely technology, organization, and environment, that affect the adoption of emerging technologies [43]. In this framework, technology refers to the internal and external technical knowledge of an organization, as well as the mechanization that may influence the adoption decision. Besides, the characteristics of the company, including its particular communications channels and resources, are under the organization aspects, while the external forces such as competition and the regulatory and market conditions sit within the environment aspect $[43,85,86]$.

\subsubsection{DOI Model}

DOI theory uses five phases to explain how the innovation process works within an organization [25]. The five phases are knowledge, persuasion, decision, implementation, and confirmation [55]. This theory is broad-based and provides a persuasive explanation for the process of adopting innovation by any organization. By focusing on this process, DOI theory offers a complementary perspective because it focuses more on the technological aspects of the TOE framework, and the use of the two frameworks makes everyone has a complementary advantage.

The TOE framework and the DOI model are used widely to examine the adoption of technology at the organizational level $[31,32,35,78-84]$. We carry out an analysis of the adoption theories used in the literature. Table 2 shows that authors apply one or more theoretical models to build their research models. Nevertheless, it is not possible to apply a single theory to all types of innovations [87]. Therefore, an incorporated model of theories is desirable, to be used in deciding the adoption process of certain types of innovation.

Table 2. Mapping matrix of the model theories.

\begin{tabular}{|c|c|c|c|c|c|}
\hline \multirow[b]{2}{*}{ Theory/Model } & \multirow[b]{2}{*}{ Definition } & \multirow[b]{2}{*}{ Justification } & \multirow[b]{2}{*}{ Limitation } & \multicolumn{2}{|c|}{ Previous Studies } \\
\hline & & & & $\begin{array}{c}\text { IT Adoption } \\
\text { (Dependent Variable) }\end{array}$ & Source \\
\hline \multirow{7}{*}{ TOE } & \multirow{7}{*}{$\begin{array}{l}\text { The aim of TOE } \\
\text { framework [ } 43] \text { is to clarify the } \\
\text { procedure for innovation } \\
\text { adoption at the organizational } \\
\text { level. It looks into three } \\
\text { contexts that affect the use of } \\
\text { an innovation in a firm - the } \\
\text { organization, the technology, } \\
\text { and the environment context. }\end{array}$} & \multirow{7}{*}{$\begin{array}{l}\text { TOE model has a wide power across a number of } \\
\text { technological, industrial, and national/cultural } \\
\text { contexts [88-90]. } \\
\text { TOE framework can be applied in empirical research } \\
\text { since new technologies are developed, especially when } \\
\text { novel contexts for adoption can be identified [91]. }\end{array}$} & \multirow{7}{*}{$\begin{array}{l}\text { TOE does not offer a } \\
\text { robust model for relating } \\
\text { the factors that affect the } \\
\text { organizational } \\
\text { acceptance decision } \\
\text { making; instead, it gives } \\
\text { a taxonomy for } \\
\text { classifying adoption } \\
\text { factors in their } \\
\text { individual contexts. } \\
\text { Researchers are advised } \\
\text { to take a wider context } \\
\text { into consideration in } \\
\text { which improvement } \\
\text { takes place [92]. }\end{array}$} & Mobile supply chain & [93] \\
\hline & & & & $\begin{array}{l}\text { Radio frequency } \\
\text { identification (RFID) }\end{array}$ & [94-96] \\
\hline & & & & Green IT & {$[92,97]$} \\
\hline & & & & $\begin{array}{l}\text { Interorganizational } \\
\text { business process } \\
\text { standards }\end{array}$ & [98] \\
\hline & & & & E-business & $\begin{array}{l}{[86,99,} \\
100]\end{array}$ \\
\hline & & & & SaaS & [101] \\
\hline & & & & Cloud computing & $\begin{array}{l}{[102,} \\
103]\end{array}$ \\
\hline \multirow{5}{*}{ DOI } & \multirow{5}{*}{$\begin{array}{l}\text { DOI theory [104] gives a } \\
\text { detailed explanation on the } \\
\text { diffusion of innovation within } \\
\text { an organization. According to } \\
\text { DOI theory, an innovation } \\
\text { undergoes a number of stage } \\
\text { procedures until it thrives in } \\
\text { the firm [105]. }\end{array}$} & \multirow{5}{*}{$\begin{array}{l}\text { DOI theory gives a broader standpoint on the diffusion } \\
\text { incident and gives a good explanation on how new } \\
\text { innovations are applied. Therefore, DOI enriches the } \\
\text { technological context of the TOE framework, and thus } \\
\text { gains value when applied in conjunction with the TOE } \\
\text { framework [84]. }\end{array}$} & \multirow{5}{*}{$\begin{array}{l}\text { It is not possible to apply } \\
\text { a single theory to all } \\
\text { types of innovations [87]. }\end{array}$} & Internet & [106] \\
\hline & & & & E-procurement & [107] \\
\hline & & & & RFID & [108] \\
\hline & & & & E-business & $\begin{array}{l}{[100,} \\
109]\end{array}$ \\
\hline & & & & Cloud computing & [103] \\
\hline \multirow{5}{*}{ TOE and DOI } & & \multirow{5}{*}{$\begin{array}{l}\text { DOI theory makes a wide standpoint available on the } \\
\text { diffusion phenomenon, and it gives excellent } \\
\text { explanations on how new innovations are chosen. } \\
\text { Therefore, DOI enriches the technological context of } \\
\text { the TOE structure, and thereby obtain value when } \\
\text { applied in conjunction with TOE framework [84]. }\end{array}$} & & Benchmarking & [107] \\
\hline & & & & $\begin{array}{l}\text { Collaborative } \\
\text { commerce }\end{array}$ & [110] \\
\hline & & & & E-commerce & [79] \\
\hline & & & & Open source & [111] \\
\hline & & & & $\begin{array}{l}\text { Digital } \\
\text { transformation }\end{array}$ & [112] \\
\hline TOE and INT & & $\begin{array}{l}\text { INT benefits TOE by enriching the environmental } \\
\text { context of TOE framework [28-30], so it gains value } \\
\text { when used in combination with the TOE structure [21]. }\end{array}$ & & $\begin{array}{l}\text { Scope of ecommerce } \\
\text { use }\end{array}$ & [113] \\
\hline \multirow{2}{*}{$\begin{array}{l}\text { TOE, DOI and } \\
\text { INT }\end{array}$} & & \multirow{2}{*}{$\begin{array}{l}\text { A combination of DOI theory, TOE framework, } \\
\text { and INT theory thus gives a theoretically solid basis to } \\
\text { evaluate the technology, organization, } \\
\text { and environment characteristics [84]. }\end{array}$} & & E-procurement & {$[63]$} \\
\hline & & & & $\begin{array}{l}\text { SaaS diffusion in } \\
\text { firms }\end{array}$ & [84] \\
\hline TOE and ECM & & $\begin{array}{l}\text { It is imperative to incorporate not only } \\
\text { technology-level factors from the IS continuance } \\
\text { literature, but also new constructs and relationships } \\
\text { that capture the complex nature of organization-level } \\
\text { decisions }[114,115] \text {. }\end{array}$ & & $\begin{array}{l}\text { Enterprise } 2.0 \\
\text { post-adoption }\end{array}$ & [115] \\
\hline
\end{tabular}




\subsection{Analysis Techniques}

Statistical analysis has been an essential tool for researchers for more than a century to extend their ability to develop, explore, and confirm research findings. Statistical methods' applications have expanded recently with the advent of computer technologies [116]. In this section, we explain two analytical approaches, and why the purpose of their employment in this study.

\subsubsection{Structural Equation Modeling}

Structural equation modeling (SEM) is a second-generation multivariate data analysis method that is used to either explore or confirm theory [116]. There are two types of SEM-one is covariance-based, and the other is variance-based. CBSEM is used to confirm (or reject) theories. Variance-based structural equation modeling (i.e., PLS-SEM) is primarily used for exploratory research and the development of theories [116]. To validating the measurement and structural model, Variance-based structural equation modeling (PLS-SEM) was applied to the collected data with SmartPLS 3.0.

\subsubsection{Neural Network}

The neural network can be explained as a significant parallel distributed processor, consisting of simple processing units that are naturally inclined to store experimental knowledge and to provide access for use [117]. Moreover, a neural network is considered to be similar to the human brain and is capable of attaining new knowledge from its surroundings by implementing the learning process. Then, the synaptic weights store this acquired knowledge [117]. Following this, the learning algorithm uses sample data for altering the synaptic weights of the neural network in an orderly fashion in order to achieve the design objective [117]. Moreover, the neural network offers numerous benefits than traditional statistical methods. Such benefits include non-linear and linear neural networks to enable the assessment of non-compensatory decision processes, and it can help attain the input and output mapping without requiring specific distribution concerning the output or input [118]. Furthermore, the adaptivity of the neural network suggests that it is able to address the data generation process in terms of structural changes and that it is not difficult to re-train it according to environmental changes $[118,119]$. It has also been noted that neural networks surpass traditional compensatory models such as multiple, discriminant, and logistic regression analyses [118,119]. However, despite the fact that neural network has been implemented in studies in different fields such as economics [120], customer loyalty [121], wearable healthcare devices [122], and consumer choice [119,123], few studies have focused on its information systems applications [124]. Hence, the present study will first utilize PLS-SEM to determine the constructs that have strong relationships with the adoption of CC in HEIs, and then implement the non-compensatory neural network model for foreseeing the adoption of CC in HEIs according to the critical adoption variables.

\section{Hypotheses and Model Development}

A research hypothesis is defined as a "logically conjectured relationship between two or more variables expressed in the form of a testable statement" [125]. For this reason, the assumptions of the current study are discussed below.

\subsection{Compatibility}

In DOI theory, compatibility is the first variable that is expected to be able to foresee CC adoption. This is also called the extent to which an innovation matches the past practices, current values, and present needs of the potential adopter [104]. Moreover, compatibility examined how much innovation can conform to the existing systems. It has also been noted that the characteristics of a new technology innovation can impact potential innovation adopters. Further, DOI studies have accentuated how significant compatibility is when assessing the disposition of organizations for implementing new technology $[104,126]$. 
Several studies have examined compatibility as an important addition to the variance concerning IT managers' inclination to adopt CC $[30,31,35,127,128]$. Hence, the following hypothesis is devised:

Hypothesis $\mathbf{1}$ (H1). Compatibility positively impacts CC adoption in HEIs.

\subsection{Competitive Pressure}

Competitive pressure is the perceived pressure by the leaders of an institution when CC services help competitors to achieved substantial competitive advantage in teaching and learning effectiveness $[115,129,130]$. Literature has studied competitive pressure as a significant construct, affecting the use of CC in various contexts $[100,112,115,131-133]$. Therefore, the second hypothesis is as follows:

Hypothesis 2 (H2). Competitive pressure positively influences CC adoption in HEIs.

\subsection{Complexity}

Complexity refers to the perceived difficulty of the organization regarding comprehending and utilizing an innovation [134]. If the relevant innovation is deemed to be difficult to use, it reduces the possibility of adoption [104]. A meta-analysis study was conducted by Tornatzky and Klein [135] where they observed that compatibility and complexity formed the major attributes concerning technology innovation behavior. The DOI literature also highlights the importance of determining the complexity of organizations in their tendencies to implement new technologies $[104,126]$.

Previous literature has studied complexity as the most significant construct, influencing CC adoption $[30,31,35,127,128]$. It is, therefore, hypothesized that:

Hypothesis 3 (H3). Complexity negatively influences CC adoption in HEIs.

\subsection{Cost Savings}

Cost savings refer to the decreased capital investment needed in an institution for IT service leased resources and hardware solutions [136]. The storage and delivery services provided by CC have significantly reduced the cost [137], which has made it a valuable solution in the current financial crisis to maintain the quality of services by the institutions [138]. Cloud computing technology is based on Internet technologies and cost-effectiveness as key distinguishing characteristics of CC [139] which can influence its adoption. Researchers found that perceived higher cost saving led to higher intention to adopt an innovation [140,141]. Based on the literature, it is postulated that:

Hypothesis 4 (H4). Cost saving positively influences CC adoption in HEIs.

\subsection{Vendor Support}

Top management literature suggests that IT service provider or vendor also plays a very important role in the decision of IT services adoption [142,143]. Vendor support in the case of CC services is far more crucial because cloud-based IT services from a capable vendor may enhance the internal capabilities of an organization [144]. Vendors provide cloud-based services, which can be dynamically priced and can be scaled up/down according to the requirements. This flexibility enables the client institution to develop and enhance their capabilities. However, only capable service providers will be able to provide these benefits. Therefore, it is hypothesized that:

Hypothesis 5 (H5). Vendor support positively influences CC adoption in HEIs. 


\subsection{Technology Readiness}

Technology Readiness captures the internal technical resources of the organization [112]. A meta-analysis [145] asserted the technology readiness importance for IS adoption and impact. Mata, Fuerst [146] recommended technology readiness to be composed of technology infrastructure and IT skills.

Before adopting CC technology, it is important to know the readiness of an HEI. The HEI needs to promote the technology readiness of $\mathrm{CC}$, and the Internet bandwidth should be sufficient for cloud access by all students and teachers. Instructional content should be ready to run on the cloud. Teachers and students need to have appropriate devices and an adequate internet connection to support the CC initiative [147].

Recent studies on CC adoption using DOI did find that technological readiness still has a significant impact on the adoption of CC $[18,33,39,84,147]$. Therefore, it is hypothesized that:

Hypothesis 6 (H6). Technology readiness positively influences CC adoption in HEIs.

\subsection{Top Management Support}

Top management support [18] refers to the top management's attitude regarding the concerned technology as well as the extent of support given to the adoption. In terms of a strategic perspective, the successful implementation of CC in HEIs depends on the capabilities of top leadership or management to drive the change from traditional deployment to CC through an official pro-cloud strategy [148]. The decision-makers' awareness and consensus are vital. Their support will ensure what cloud services are needed and what type of cloud deployment is best for HEIs settings. To do that, the decision-makers have to understand the benefits of cloud-based services, the value they can add to the educational services, and how to migrate to the CC environment [149]. Accordingly, it is hypothesized that:

Hypothesis 7 (H7). Top management support positively influences CC adoption in HEIs.

\subsection{Security}

Despite the boom in CC with new features and market access, security in CC remains the biggest problem hindering the adoption of CC services [31,37].

Security is one of the crucial technical problems concerning CC adoption. Cloud vendors are trying to simulate the classic principles of confidentiality, availability, and integrity, which are commonly found in physical systems for distributed, virtualized, and dynamic cloud systems that are accessed online [150]. Three service models are used in CC (SaaS, PaaS, and IaaS) and four deployment models (public, private, community, and hybrid), which require different levels of security for each model to protect the user's data [151]. Internet security vulnerabilities have been an issue for users for years, such as e-commerce and online banking. Hence, the importance of security in IT environment of HEIs is critical $[148,152,153]$. Because CC is based on Internet technology, the same security issues hinder its adoption. However, the advanced security algorithms used in CC have been identified as the main differentiators of CC [139] that can influence its adoption. Previous studies have considered security as an influencing factor in adopting CC services $[31,33,37,38,147]$. Accordingly, it is hypothesized that:

Hypothesis 8 (H8). Data security negatively influences CC adoption in HEIs.

\subsection{Research Model}

Based on the theoretical and conceptual background outlined previously, this research used a method that complements existing constructs in the DOI model through the lens of the TOE framework using constructs from the previous empirical literature on adoption research (see Table 2) to the context of IS adoption in HEIs. The importance of using these theoretical perspectives gives a theoretical basis 
to assess the task, organization, technology, and environment characteristics that affect CC adoption in HEIs, and this has received empirical support consistently [71,82-84,93,97,110,154,155]. To be able to include the various and wide list of factors from past search and filter them, we undertook a process of collaborating, matching, filtering, and consolidating for all the information and ideas from the past studies, discussed in the literature review $[156,157]$. Eventually, the most frequent factors were selected. Table 3 shows the mapping matrix of the related adoption theories and factors, obtained from previous literature.

Table 3. Mapping matrix of the model factors from TOE framework and DOI theory.

\begin{tabular}{|c|c|c|c|c|c|c|c|c|c|c|}
\hline \multirow[b]{2}{*}{$\begin{array}{l}\text { Model/ } \\
\text { Theory }\end{array}$} & \multirow[b]{2}{*}{$\begin{array}{c}\text { Technology/ } \\
\text { Dependent Variable }\end{array}$} & \multirow[b]{2}{*}{ 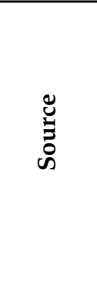 } & \multicolumn{8}{|c|}{ Factors/Independent Variables } \\
\hline & & & 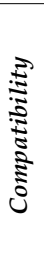 & 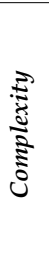 & 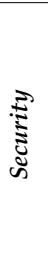 & 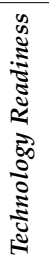 & 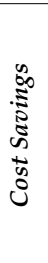 & 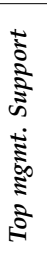 & 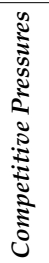 & 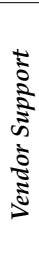 \\
\hline TOE & Cloud migration & [18] & & & $\times$ & & & $x$ & & \\
\hline DOI and others & CC adoption & {$[30,31]$} & $x$ & $\times$ & $\times$ & $\times$ & $\times$ & & & \\
\hline TOE & Open systems & [158] & & $\times$ & & & & & & \\
\hline TOE & Electronic data interchange & [159] & & & & $\times$ & $\times$ & & & \\
\hline TOE & E-business use & [85] & & & & $\times$ & & & & \\
\hline DOI and TOE & E-business use & [112] & $x$ & $\times$ & $\times$ & $\times$ & $\times$ & & & \\
\hline TOE & E-business adoption & [100] & & & & $\times$ & & & & \\
\hline TOE & E-business & [80] & $x$ & & & & & & & \\
\hline TOE & $\begin{array}{l}\text { Knowledge management and } \\
\text { enterprise systems }\end{array}$ & [81] & $\times$ & $\times$ & & & & $\times$ & & \\
\hline DOI and TOE & Collaborative commerce & [110] & $x$ & $\times$ & & & & $\times$ & & \\
\hline DOI, TOE, and others & Internet utilization & [106] & & & & $\times$ & $\times$ & $\times$ & & \\
\hline DOI, TOE, and others & Cloud-based services adoption & [144] & & & & & & $\times$ & & $x$ \\
\hline DOI and TOE & Benchmarking & [107] & $x$ & $x$ & & & & & & \\
\hline DOI & RFID & [108] & & $\times$ & & & & $\times$ & & \\
\hline TOE and others & E-business adoption & [86] & & & & $\times$ & & & & \\
\hline TOE & E-commerce & [160] & $x$ & & & & $\times$ & $\times$ & & \\
\hline TOE & Internet/E-business & [109] & $\times$ & $\times$ & & & & $\times$ & & \\
\hline TOE & RFID adoption & [161] & $x$ & $\times$ & & & $x$ & $x$ & & \\
\hline DOI and TOE & CC adoption & [103] & $x$ & $\times$ & & $\times$ & $\times$ & $\times$ & $\times$ & \\
\hline DOI & $\begin{array}{l}\text { Internet-based purchasing } \\
\text { application assimilation }\end{array}$ & [162] & $x$ & $\times$ & & & & & & \\
\hline DOI & CC adoption & [163] & $x$ & $\times$ & & & & & & \\
\hline TOE & CC adoption & [164] & $x$ & $x$ & $x$ & & $x$ & & & \\
\hline TOE & CC adoption & [165] & $\times$ & $x$ & & & $x$ & $x$ & $x$ & $x$ \\
\hline TOE & CC adoption & [102] & $x$ & $x$ & & $\times$ & $x$ & $x$ & $x$ & \\
\hline DOI and others & CC adoption & [166] & $x$ & $x$ & & & & & & \\
\hline TOE and DOI & CC adoption & [84] & $x$ & $x$ & $x$ & $\times$ & $\times$ & $\times$ & $x$ & \\
\hline TOE, DOI, and INT & SaaS diffusion in firms & [84] & $x$ & $x$ & $x$ & $\times$ & $\times$ & $x$ & $\times$ & \\
\hline TOE and TAM & CC adoption & [167] & $x$ & $x$ & & $\times$ & & & $x$ & $x$ \\
\hline TOE and TAM & CC adoption & [167] & $x$ & $x$ & & & & $x$ & $x$ & \\
\hline TOE and TAM & CC adoption & [89] & $\times$ & $\times$ & & & & $\times$ & $\times$ & \\
\hline DOI and FVM & CC adoption & {$[82]$} & $\times$ & $\times$ & $\times$ & $\times$ & $\times$ & $\times$ & & \\
\hline FVM, TOE and DOI & Cloud ERP Adoption & [168] & $\times$ & & $x$ & & $x$ & $x$ & & \\
\hline This study & & & $x$ & $x$ & $x$ & $\times$ & $x$ & $x$ & $x$ & $x$ \\
\hline
\end{tabular}


We also formulated a related hypothesis to specify the purpose of the research, highlight future areas of research, and to consolidate knowledge relating to CC adoption. Figure 1 provides an overview of the research proposed model. The research model demonstrates that compatibility, complexity, security, technology readiness, cost savings, top management support, competitive pressure, and vendor support factors will have a significant relationship with the CC adoption in HEIs. The model is grounded at the organizational level of analysis [157], and the smallest unit of analysis is an individual of CC.

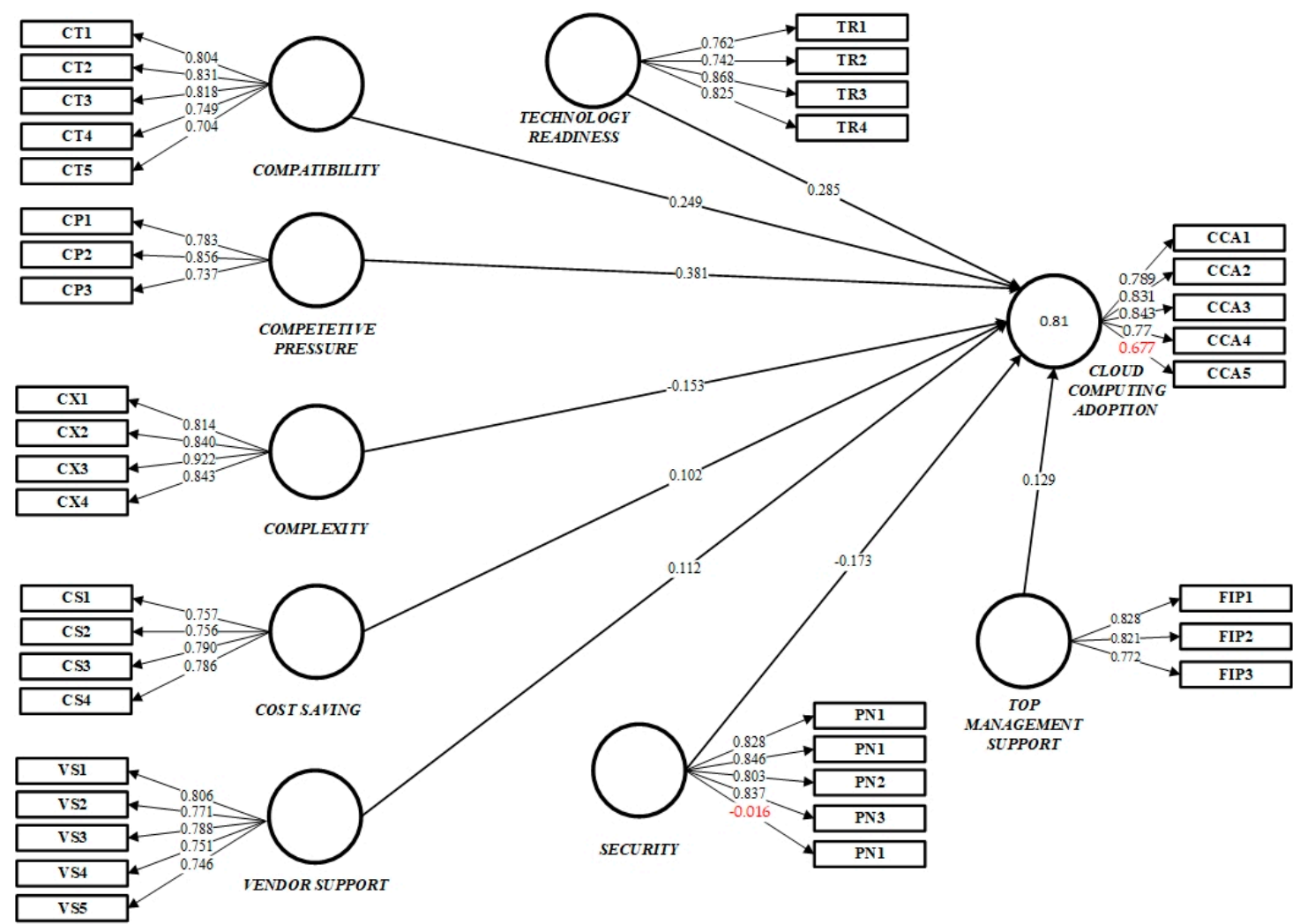

Figure 1. Proposed model.

\section{Methodology}

The proposed study applied two stages of analysis methods, namely variance-based structural equation modeling (PLS-SEM) and artificial neural networks (ANN). The reliability and validity of the measurement model and also hypotheses were tested by SEM, while the neural network was employed for the predictors and antecedents of CC adoption [45]. As indicated by Chan and Chong [169], to validate the relationship of hypotheses in behavioral and social science, PLS-SEM is frequently used; however, it is seldom integrated with other artificial intelligence algorithms. As PLS-SEM is employed for the linear model, it may often simplify the complications in making technology adoption decisions [170]. To solve this issue, the neural network method was used to recognize the non-linear relationships between predictors in the proposed research model. According to Chan and Chong [169], ANN helps to learn complex linear and non-linear associations between the factors of technology adoption and adoption decisions. Moreover, the ANN makes it possible to perform more precise anticipation in comparison to the general regression procedure [171]. However, some researchers applied a combination of ANN and PLS-SEM analysis in diverse adoption settings, such as CRM adoption Ahani, Rahim [172], CC Sharma, Al-Badi [66], and wearable healthcare devices and IOS adoption Chong and Bai [173]. Therefore, at the main phase, to find the factors that have an important influence on the adoption of CC, this study applied SEM. The ANN approach was employed in the 
second phase for predicting the CC adoption, based on the considerable factors resulted from the PLS-SEM analysis.

\section{Sampling and Data Collection}

Quantitative studies can utilize probability as well as non-probability sampling approaches. However, the non-probability sampling approach is mainly used for qualitative studies [174]. Generalizing the results driven from a small group of people to large groups is the key advantage of the quantitative research method. [175]. Daniel [174] declared that "in purposive sampling researcher purposely selects the elements because they satisfy specific inclusion and exclusion criteria for participation in the study." Purposive sampling is suitable for the initial phases of study where subjects have not much experience with a particular event under investigation [176]. Therefore, this study adopted a purposive sampling approach, and the target population of the study is the individuals who are related to the decision of adopting CC services in the institution (e.g., ICT directors, administrators, information technology officers, etc.) and can provide recommendations regarding the adoption of CC services. The summary of the respondent's characteristics in Table 2 shows that most of the respondents have advance or expert level in computer literature (i.e., $57.46 \%$ and $35.07 \%$ respectively) and $1-5$ years or $6-10$ years of experience in the field (i.e., $81.34 \%$ and $15.67 \%$ respectively). Face validity, content validity, and a pilot study were performed to ensure the validity and reliability of the questionnaire. For most scholars, a pilot study sample size of 20-40 is reasonable [177-182]. In this regard, our pilot study's reliability statistic was based on 30 online completed questionnaires. Structural equation modeling (SEM) was applied to the pilot data with SmartPLS 3.0 [116]. The results of a pilot study, conducted through a survey with ICT decision-makers, and based on the proposed conceptual model, indicate that the instrument is both reliable and valid, and so point the way towards further research. It is worth drawing attention to the fact that the questions were adapted from prior empirical literature that had been validated by previous researchers (see Appendix A). Data were collected online from May to July 2019. After three months, a total of 148 responses to the survey questionnaire were received by researchers. After data screening, some questionnaires with a missing value were excluded, and a total of 134 responses were found valid for the analysis. The demographic information of the respondents is presented in Table 4.

Table 4. Characteristics of the respondents.

\begin{tabular}{lcc}
\hline \multicolumn{2}{c}{ Respondents Information } \\
\hline \multicolumn{2}{c}{ Frequency } & Percentage \\
\hline Computer literacy level & 1 & \\
Beginner & 9 & $0.75 \%$ \\
Intermediate & 77 & $6.72 \%$ \\
Advanced & 47 & $57.46 \%$ \\
Expert & & $35.07 \%$ \\
\hline Experience & 109 & \\
1-5 years & 21 & $81.34 \%$ \\
6-10 years & 4 & $15.67 \%$ \\
11-15 years & 0 & $2.99 \%$ \\
More than 15 years & & 0 \\
\hline Job title & 19 & \\
Administrator & 13 & $14.17 \%$ \\
Lecturer & 3 & $9.70 \%$ \\
Teaching staff & 26 & $2.38 \%$ \\
ICT director & 11 & $19.40 \%$ \\
Chief information officer & 4 & $8.21 \%$ \\
IT specialist & 2 & $2.98 \%$ \\
Business analyst & 53 & $1.49 \%$ \\
Researcher & 3 & $39.55 \%$ \\
Associate professor & & $2.23 \%$ \\
\hline &
\end{tabular}




\section{Data Analysis and Results}

This study applied two analytical approaches, namely variance-based structural equation modeling (PLS-SEM) and artificial neural network (ANN). First, the PLS-SEM approach has been used for analyzing the proposed model and extracting the significant relationships among the identified factors. The obtained result from PLS-SEM analysis revealed that factors identified significant in influencing decision-makers' intention towards adopting CC. Second, the normalized importance among those significant predictors was ranked utilizing the ANN. This section explains the data analysis and results in detail.

\subsection{Analysis of PLS-SEM Results}

A variance-based technique (i.e., PLS-SEM) was used to analyze the structural model, and this decision was made for several reasons: firstly, the partial least squares (PLS) method is effective for small-to-moderately-sized samples, and it provides parameter estimates even at reduced sample sizes [183,184]; secondly, PLS is viable for exploratory research [185], particularly when examining new structural paths in the context of incremental studies that extend previous models [186], or when the relationships and measures proposed are new or have not been extensively examined in prior literature [187,188]; and thirdly, the variance-based approach in PLS is effective for predictive applications. Therefore, since the study's objective was to identify the factors underlying CC adoption, PLS was a suitable choice [189].

\subsubsection{Measurement Model Assessment}

SEM is composed of two-step process measurement and structural model assessments. The measurement model assessment is the first step of the model assessment, to ensure that every construct is measured correctly. Reliability and validity are the primary requirement for measurement model assessment to measure the strength of the suggested model. According to Hair Jr, Hult [116], "for internal consistency of the measurement model composite reliability and Cronbach's $\alpha$ were applied." The validity of the constructs was evaluated by applying "average variance extracted (AVE)" and "cross-factor loadings." The reliability and validity results of the specified constructs were summarized in Table 5. As recommended by Hair Jr, Hult [116] for the reliability of the constructs, the value above 0.7 is a satisfactory score for the internal consistency of the survey. For all defined constructs, the results showed that composite reliability and Cronbach's $\alpha$ are above the satisfactory value of 0.7, which surpasses the suggested score, except CCA5 and VS5. Furthermore, the minimum score of 0.50 is considered to be an acceptable value of AVE for each construct [116]. As depicted in Table 5, the validity of scale items was above 0.5 , which exceeded the threshold value. The next step after convergent validity verification is discriminant validity. The "discriminant validity" was evaluated by analyzing correlations between the constructs [190]. As revealed in Table 6, the Square root of AVE for defined constructs had a higher value in comparison to correlation co-efficient with other latent constructs. Therefore, "convergent and discriminant validity" was approved in the assessment of the measurement model [190]. Consequently, based on the above assessments, the validity and reliability of the constructs for the measurement model have been accepted and meet the recommended values.

Table 5. Constructs' reliability and validity.

\begin{tabular}{cclccc}
\hline Constructs & Items & OL $(>\mathbf{0 . 7})$ & CA (>0.6) & CR (>0.7) & AVE (>0.5) \\
\hline \multirow{5}{*}{ CC Adoption } & CCA1 & 0.789 & & & \\
& CCA2 & 0.831 & & & \\
& CCA3 & 0.843 & 0.842 & 0.888 & 0.615 \\
& CCA4 & 0.77 & & & \\
& CCA5 & 0.677 & & & \\
\hline \multirow{5}{*}{ Compatibility } & CT1 & 0.804 & & 0.612 \\
& CT2 & 0.831 & & & \\
& CT3 & 0.818 & 0.842 & & \\
\hline
\end{tabular}


Table 5. Cont.

\begin{tabular}{|c|c|c|c|c|c|}
\hline Constructs & Items & OL $(>0.7)$ & $\mathrm{CA}(>0.6)$ & $\mathrm{CR}(>0.7)$ & $\operatorname{AVE}(>0.5)$ \\
\hline \multirow{3}{*}{ Competitive pressure } & CP1 & 0.783 & \multirow{3}{*}{0.71} & \multirow{3}{*}{0.836} & \multirow{3}{*}{0.63} \\
\hline & $\mathrm{CP} 2$ & 0.856 & & & \\
\hline & $\mathrm{CP} 3$ & 0.737 & & & \\
\hline \multirow{4}{*}{ Complexity } & CX1 & 0.814 & \multirow{4}{*}{0.879} & \multirow{4}{*}{0.916} & \multirow{4}{*}{0.732} \\
\hline & CX2 & 0.84 & & & \\
\hline & CX3 & 0.922 & & & \\
\hline & CX4 & 0.843 & & & \\
\hline \multirow{4}{*}{ Cost saving } & CS1 & 0.757 & \multirow{4}{*}{0.772} & \multirow{4}{*}{0.852} & \multirow{4}{*}{0.59} \\
\hline & CS2 & 0.756 & & & \\
\hline & CS3 & 0.79 & & & \\
\hline & CS4 & 0.768 & & & \\
\hline \multirow{5}{*}{ Vendor support } & VS1 & 0.806 & \multirow{5}{*}{0.832} & \multirow{5}{*}{0.881} & \multirow{5}{*}{0.597} \\
\hline & VS2 & 0.771 & & & \\
\hline & VS3 & 0.788 & & & \\
\hline & VS4 & 0.751 & & & \\
\hline & VS5 & 0.746 & & & \\
\hline \multirow{4}{*}{ Technology readiness } & TR1 & 0.762 & \multirow{4}{*}{0.812} & \multirow{4}{*}{0.877} & \multirow{4}{*}{0.642} \\
\hline & TR2 & 0.742 & & & \\
\hline & TR3 & 0.868 & & & \\
\hline & TR4 & 0.825 & & & \\
\hline \multirow{3}{*}{ Top Manager's support } & TMS1 & 0.828 & \multirow{3}{*}{0.734} & \multirow{3}{*}{0.849} & \multirow{3}{*}{0.652} \\
\hline & TMS2 & 0.821 & & & \\
\hline & TMS3 & 0.772 & & & \\
\hline \multirow{5}{*}{ Security } & SC1 & 0.828 & \multirow{5}{*}{0.74} & \multirow{5}{*}{0.829} & \multirow{5}{*}{0.55} \\
\hline & SC2 & 0.846 & & & \\
\hline & SC3 & 0.803 & & & \\
\hline & SC4 & 0.837 & & & \\
\hline & SC5 & -0.016 & & & \\
\hline
\end{tabular}

$\mathrm{OL}=$ Outer loading, $\mathrm{CA}=$ Cronbach's alpha, $\mathrm{CR}=$ Composite reliability, AVE $=$ Average variance extracted.

Table 6. Fornell-Larckers criterion analysis construct.

\begin{tabular}{cccccccccc}
\hline & CC & CT & CP & CX & CS & VS & TR & TMS & SC \\
\hline CCA & $\mathbf{0 . 7 8 4}$ & & & & & & & & \\
CT & 0.684 & $\mathbf{0 . 7 8 3}$ & & & & & & & \\
CP & 0.78 & 0.62 & $\mathbf{0 . 7 9 4}$ & & & & & & \\
CX & 0.369 & 0.613 & 0.417 & $\mathbf{0 . 8 5 6}$ & & & & & \\
CS & 0.586 & 0.489 & 0.475 & 0.331 & $\mathbf{0 . 7 6 8}$ & & & & \\
VS & 0.677 & 0.621 & 0.637 & 0.545 & 0.492 & $\mathbf{0 . 7 7 3}$ & & & \\
TR & 0.721 & 0.509 & 0.577 & 0.356 & 0.479 & 0.535 & $\mathbf{0 . 8 0 1}$ & & \\
TMS & 0.669 & 0.549 & 0.615 & 0.36 & 0.486 & 0.643 & 0.474 & $\mathbf{0 . 8 0 7}$ & \\
SC & 0.547 & 0.569 & 0.682 & 0.4 & 0.499 & 0.535 & 0.509 & 0.521 & $\mathbf{0 . 7 4 1}$ \\
\hline
\end{tabular}

Note: CC adoption (CCA); Compatibility (CT); Competitive pressure (CP); Complexity (CX); Cost saving (CS); Vendor support; Technology readiness (TR); Top manager's support (TMS); Security (SC).

\subsubsection{Structural Model Assessment}

In the PLS-SEM analysis, after analyzing the measurement model for getting approval for the reliability and validity of the defined constructs, the next step was the structural model assessment. In PLS-SEM as recommend by Hair Jr, Hult [116], for testing the predictive power of the structural model, researchers measured R-Square, and path coefficient between the constructs was used. Total predicted $\mathrm{R}^{2}$ for the dependent variable (intention) is 0.81 , which represents substantial coefficients of determination [116]. The result of the hypothesis testing and path coefficients for the structural model was measured, and the findings are shown in Table 7. The values for " $t=3.091$ " and " $p<0.001$ ", " $t=2.326$ " and " $p<0.01$ ", and " $t=1.645$ " and " $p<0.05$ " can be accepted for $t$-value at various significance levels [138]. The result of the hypotheses calculation by running bootstrapping shows that all the proposed CC adoption antecedent factors had a significant influence on it, except vendor support. Based on the analysis, CC adoption is positively influenced by compatibility ( $\beta=0.249$, $t$-value $=4.311$, $p<0.01)$. Thus, this hypothesis supported. Competitive pressure $(\beta=0.381, t$-value $=5.516, p<0.01)$ 
has positive significant influence on $C \mathrm{C}$ adoption. The complexity has a negative significant influence on CC adoption ( $\beta=-0.153, t$-value $=2.887, p<0.01$ ); therefore, this hypothesis is also supported. Cost saving is another factor which had significant and positive influence on CC adoption $(\beta=0.102$, $t$-value $=2.266, p<0.05)$. However, vendor support $(\beta=0.112, t$-value $=1.447, p>0.05)$ does not have a significant influence on CC adoption, and this hypothesis is not supported. Furthermore, from the analysis, CC adoption is positively influenced by technology readiness $(\beta=0.285, t$-value $=4.888$, $p<0.01)$. The results indicated that the top manager's support has a positive and significant influence on CC adoption $(\beta=0.129, t$-value $=1.978, p<0.05)$. Meanwhile, from the analysis, it shows that CC adoption is negatively and significantly influenced by security $(\beta=-0.173, t$-value $=2.226, p<0.05)$. It is clear from the result that among all the constructs, competitive pressure had the highest significant level and was the most significant factor that was selected and influenced the individuals' intention for the adoption of CC in higher education, followed by the technology readiness, which had higher significance in bootstrapping analysis. As depicted in Figure 2, the result of the proposed model showed that $81 \%$ of the variance in CC adoption can be described by the technological, environmental, and organizational factors (TOE) factors.

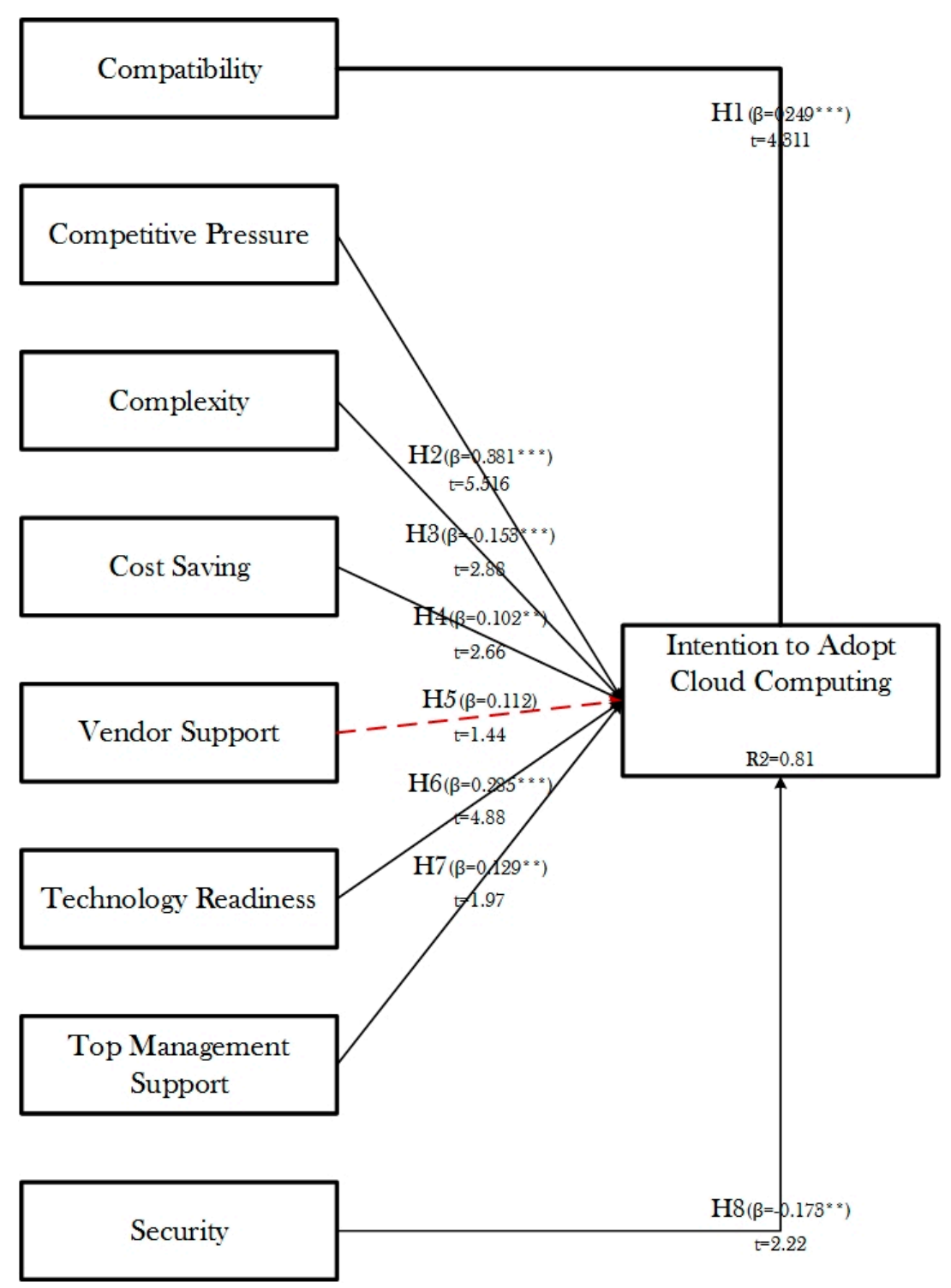

Figure 2. Results of structural model. Note: ${ }^{* *}<0.05,{ }^{* * *}<0.01$. 
Table 7. Summary of hypothesis tests.

\begin{tabular}{|c|c|c|c|c|c|c|}
\hline & $\begin{array}{c}\text { Original } \\
\text { Sample (O) }\end{array}$ & $\begin{array}{c}\text { Sample } \\
\text { Mean (M) }\end{array}$ & $\begin{array}{l}\text { Standard Deviation } \\
\text { (STDEV) }\end{array}$ & $\begin{array}{c}t \text { Value } \\
(|\mathrm{O} / \mathrm{STDEV}|)\end{array}$ & $p$ Values & Result \\
\hline Compatibility -> CC adoption & 0.249 & 0.243 & 0.058 & 4.311 & $0 * * *$ & Supported \\
\hline Competitive pressure $->C C$ adoption & 0.381 & 0.375 & 0.069 & 5.516 & $0 * * *$ & Supported \\
\hline Complexity $->$ CC adoption & -0.153 & -0.15 & 0.053 & 2.887 & $0.004^{* * *}$ & Supported \\
\hline Cost saving $->$ CC adoption & 0.102 & 0.102 & 0.045 & 2.266 & $0.023 * *$ & Supported \\
\hline Vendor support $->$ CC adoption & 0.112 & 0.117 & 0.077 & 1.447 & 0.148 & NS \\
\hline technology readiness $->C C$ adoption & 0.285 & 0.277 & 0.058 & 4.888 & $0 * * *$ & Supported \\
\hline Top manager's support -> CC adoption & 0.129 & 0.13 & 0.065 & 1.978 & $0.048^{* *}$ & Supported \\
\hline Security- $>$ CC adoption & -0.173 & -0.167 & 0.078 & 2.226 & $0.026^{* *}$ & Supported \\
\hline
\end{tabular}

\subsection{Analysis of Neural Network for Cloud Computing Adoption}

The proposed study has combined the two analytical approaches, namely PLS-SEM as a statistical approach and neural network as an artificial intelligence technique. Multiple regression analysis (MRA) and PLS-SEM are considered to be a conventional linear statistical technique, which is used for identifying the linear relationship between variables and simplify the complex decision-making process [191]. To solve this issue, it is suggested to apply the artificial neural network, which can easily recognize the non-linear relationship. According to Chan and Chong [169], the advantage of using the neural network model is that it can learn complex linear and non-linear relationships between predictors and the adoption decision. Also, the ANN is more flexible and can give better prediction accuracy as compared to the linear model(s), and it may surpass the usual statistical technique (such as MRA) [172]. However, because of its "black-box" nature, ANN is not suitable for checking the hypothesis and determining the causal relationship [191]. Thus, this paper adopted a two-stages approach, similar to [66]. In the first stage of the study, the research model is tested, and the important hypothesized predictors are analyzed using SEM. The result of the PLS-SEM is then given as input to the model of ANN, which is employed to analyze the relative significance of each predictor variable in the second stage. Hence, the results of selected factors from Smart-PLS analysis were employed to improve ANN analysis. The applied ANN has three layers: "Input layer, hidden layer, and output layer". The hidden nodes have no direct connection with the outside world (thus the name "hidden") [192]. These nodes are responsible for performing computations and transferring information from the input nodes to the output nodes [193]. As depicted in Figure 3, seven independent substantiation factors, derived from PLS-SEM analysis, are considered as the input section for ANN; whereas one dependent variable (CC adoption) is considered as the output section of ANN (see Figure 3). Wang and Elhag [194] recommended that ANNs should be calculated by varying the number of hidden nodes from one to ten. To detect the hidden nodes (H1-H10 in Figure 3), researchers such as Ahani, Rahim [172] have recommended testing the ANN model by modifying the number of hidden nodes from one to ten. The proposed research has been applied to the 10 hidden nodes to create the relative significance of the predictors. The proposed study established ANN by using R programming, as it helps to simplify and give effective results. A multilayer perception training algorithm was applied for the preparation of the ANN model (see Table 8). Hence, $70 \%$ of the data have been used as the train network model, and the remaining $30 \%$ of the data were used to test the proposed research model. Seven predicting factors, namely compatibility, competitive pressure, complexity, cost saving, technology readiness, security, and top management support, were tested. The factor "intention", which is the dependent variable in the proposed study, has been calculated in the output layer of the ANN model. The root-mean-square error (RMSE) was used to assess the precision of the ANN model that was developed [195] in both the training and testing datasets. As shown in Table 8, the average RMSE values of the training and testing procedures are relatively small at 0.1101 and 0.1022 , respectively. Therefore, this confirms that there is an excellent model fit. Besides, the importance of variable is verified based on the number of non-zero synaptic weights connected to relevant hidden parts (see Table 8), which displays that the model has 
a high predicting accuracy, based on minor RMSE scores and it shows that the model is reliable in depicting the relationship between predictors and output.

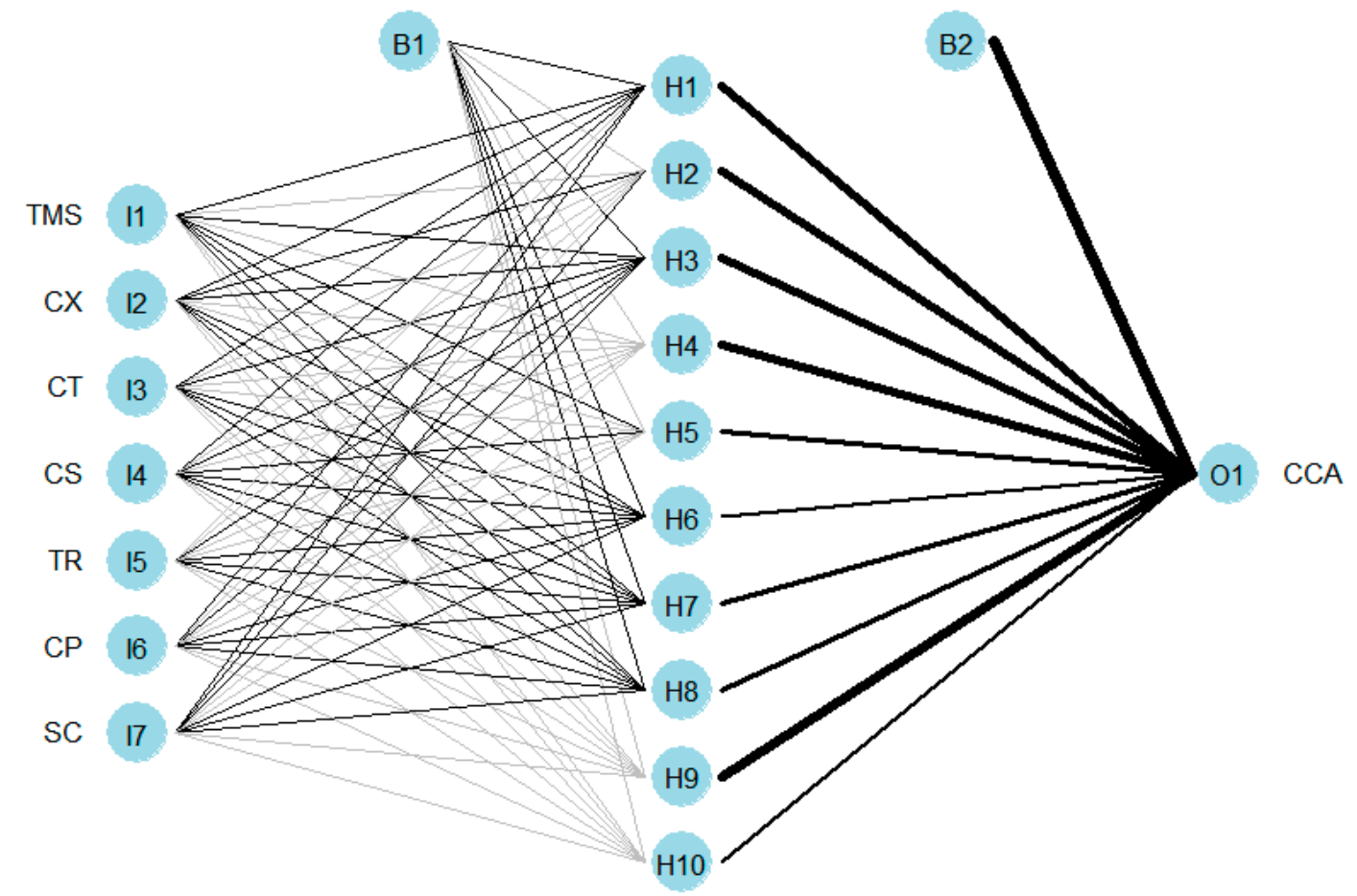

Figure 3. The anticipated ANN architect for 10 neurons. Note: CC adoption (CCA); Compatibility (CT); Competitive pressure (CP); Complexity (CX); Cost saving (CS); Technology readiness (TR); Top manager's support (TMS); Security (SC).

Table 8. RMSE values of artificial neural networks.

\begin{tabular}{ccc}
\hline Network Configures & Testing & Training \\
\hline ANN1 & 0.1174 & 0.0994 \\
ANN2 & 0.1079 & 0.1004 \\
ANN 3 & 0.1132 & 0.1013 \\
ANN 4 & 0.1105 & 0.1015 \\
ANN 5 & 0.1137 & 0.105 \\
ANN 6 & 0.1054 & 0.1015 \\
ANN 7 & 0.1069 & 0.1029 \\
ANN 8 & 0.1124 & 0.1045 \\
ANN 9 & 0.1066 & 0.1053 \\
ANN 10 & 0.1141 & 0.0973 \\
Average & 0.1101 & 0.1022 \\
Standard deviation & 0.0034 & 0.0026 \\
\hline
\end{tabular}

Therefore, all the factors are suitable for forecasting CC adoption as a dependent variable. The normalized importance is the ratio of the relative importance of each factor with its maximum relative significance, and it is stated in percentage form. Based on the PLS-SEM examination, just significant linear factors have been employed in the input parts of the ANN model. In this regard, just linear relationships have been checked. The normalized importance was calculated in the sensitivity analysis according to relative factor importance weights (see Table 9). The variable "technology readiness" resulted as the most significant factor in predicting the CC adoption, and "security" is the second important factor. 
Table 9. Normalized importance of variables.

\begin{tabular}{ccc}
\hline Variables & Importance & Normalized Importance \\
\hline TMS & 0.077 & $39.50 \%$ \\
\hline CX & 0.11 & $56.20 \%$ \\
\hline CT & 0.129 & $66.00 \%$ \\
\hline CS & 0.13 & $66.40 \%$ \\
\hline TR & 0.196 & $100.00 \%$ \\
\hline CP & 0.171 & $87.30 \%$ \\
\hline SC & 0.188 & $96.00 \%$
\end{tabular}

Note: Compatibility (CT); Competitive pressure (CP); Complexity (CX); Cost saving (CS); Technology readiness (TR); Top manager's support (TMS); Security (SC).

\section{Discussion}

Our study examined the influence of eight constructs obtained from the literature. Our research model explained $81 \%$ of the dependent variable's variance, higher than other studies that examined the adoption of cloud computing (e.g., [31,196]). Sabi, Uzoka [196] study found that their model could explain only $43 \%$, while Sabi, Uzoka [31] study found that their model could explain only $44.7 \%$. The results of the previous studies and the current investigations are compared on variously considered factors.

According to the hypotheses test, compatibility has a positive and significant impact on CC adoption. The $\beta, t$-value, and $p$-value of the test result are 0.249 , and 4.311 respectively, which is significant at the level of $p<0.01$. These values demonstrate support for this hypothesis. Besides, the ANN output revealed that the variable "compatibility" is the fourth crucial factor in the prediction of the CC adoption. Hence, the adoption of CC is significantly affected by compatibility and H1 is supported. The result corroborates what was observed in past studies ([80,81,107,110,112]). According to this research, compatibility refers to the degree to which an innovation equates the previous practices, present values, and current needs of the likely adopter [104]. In addition, compatibility looked into the extent to which an innovation can attune to available systems.

The output of the measurement model shows that competitive pressure has a significant and positive impact on CC adoption. The $\beta, t$-value, and $p$-value of the test result are $0.381,5.516$, respectively, which is significant at the level of $p<0.01$. These values demonstrate support for this hypothesis. Besides, the ANN output revealed that the variable "competitive pressure" is the third crucial factor in the prediction of CC adoption. Hence, the adoption of CC is significantly affected by competitive pressure. The result corroborates what was observed in past studies ([100,112,115,131-133]). According to this research, competitive pressure refers to the pressure observed by the leaders of an institution concerning the competitors' attainment of remarkable competitive advantage through CC services, such as the effectuality of teaching and learning $([115,129,130])$.

The stipulation of hypothesis H3 is that complexity possesses a negative impact on CC adoption. According to [134], complexity shows the observed difficulty of an institution in understanding and using innovation. If a useful innovation appears difficult to be utilized, then there will be a reduction in the likelihood of adoption [104]. As portrayed in the results of the current study, there is a significant effect of complexity on CC adoption in HEIs, because the $\beta, t$-value, and the $p$-value of complexity are $-0.153,2.887$ respectively, which is significant at the level of $p<0.01$. Therefore, complexity has a significant effect on CC adoption in HEIs. This result is in line with previous studies [30,31,35,127,128].

The output of the measurement model shows a positive impact on cost saving with CC adoption. The $\beta, t$-value, and $p$-value of the result are $0.102,2.266$ respectively, which is significant at the level of $p<0.05$. These values support the hypothesis that cost saving has a significant effect on the adoption of CC in HEIs. This result supports the findings of previous studies ([82-84,102,103,106,112,159-161,164,168]). 
According to this research, cost savings is the reduced capital investment required in an institution for IT service in terms of leased resources and hardware solutions [136].

The stipulation of hypothesis $\mathrm{H} 5$ is that vendor support has a positive impact on the adoption of CC in HEIs. According to [142,143], vendors or IT service providers are important in deciding the adoption of IT services. As shown in the results of this study, there is no significant impact of vendor support on CC adoption in HEIs, because $\beta, t$-value, and $p$-value of the result are $0.112,1.447$ respectively, which is not significant as $p>0.05$. Hence, H5 significance was unconfirmed, and the output of vendor support was insignificant, which might be due to the indicators utilized in measuring this factor being feeble. Accordingly, the study output is suggesting that further studies need to focus on the selection of powerful indicators of this construct.

The output of this measurement model shows a positive influence of technology readiness on CC adoption. The $\beta, t$-value, and $p$-value of the result is $0.285,4.888$, respectively, which is significant at the level of $p<0.01$. These values demonstrate support for this hypothesis. Besides, the ANN output revealed that the variable "technology readiness" is the second crucial factor in the prediction of the CC adoption in HEIs. Therefore, the adoption of CC is significantly affected by technology readiness. The result corroborates what was observed in past studies [18,33,39,84,147]. According to this research, technology readiness secures the internal technical resources of an organization [112]. Before the adoption of CC technology, the readiness of the institution needs to be determined. That is, HEIs must facilitate the readiness of CC technology so that the internet bandwidth needs to be adequate for student and teacher cloud accessibility.

The output of this measurement model shows a positive influence of top management support on CC adoption (H7). The $\beta, t$-value, and $p$-value of the result are $0.129,1.978$ respectively, which is significant at the level of $p<0.05$. These values demonstrate support for this hypothesis. Hence, the adoption of CC is significantly affected by top management support. This result is in line with the findings of past studies [81-84,102,103,106,108-110,160,161,168]. According to this research, the attitude of top management is important in terms of the technology involved and the degree of support provided for the adoption [18]. The knowledge and agreement of decision-makers are crucial. When they provide the necessary support, it will facilitate the needs of cloud services and the appropriate cloud deployment for HEIs settings.

Hypothesis $\mathrm{H} 8$ stipulates that security possesses a negative impact on the adoption of CC in HEIs. According to [31,37], security in CC is still the most remarkable challenge in adopting CC services. Security is a critical technical problem when it comes to adopting CC. Cloud vendors are making attempts towards the simulation of the typical principles of confidentiality, availability, and integrity usually within physical systems for distributed, virtualized, and dynamic cloud systems that users access online [150]. As shown in the results of this study, there is a significant impact of security on CC adoption in HEIs as the $\beta, t$-value, and $p$-value of the result are $-0.173,2.226$ respectively, which is significant at the level of $p<0.05$. Therefore, H5 significance was confirmed, and the output of security was significant.

\section{Implications}

\subsection{Theoretical Contribution}

This study provided empirical literature within IS, especially CC, and it provided an extensive model that integrates the TOE framework and DOI model. Also, this study provided an assessment for CC adoption in HEIs, and more revitalization of the CC and intent of decision-makers to utilize CC in HEIs.

The DOI model and TOE framework incorporation improved the ability to explain the proposed model. The proposed model was able to explain $81 \%$ of CC adoption variation, which shows that the model's ability for prediction is powerful and remarkable. Hair, Ringle [197] maintained that the $\mathrm{R}^{2}$ values of $0.75,0.50$, or 0.25 for endogenous variables show significant, moderate, or weak 
coefficients of determination. This study extends the original TOE framework regarding CC as well as the generalizability; hence, this model is useful in the assessment of the intent to adopt any other innovation. This study was able to test whether the scales utilized in the survey instrument are valid and reliable.

In conclusion, this research used a hybrid approach for the integration of PLS-SEM and ANN to validate the proposed model and to give priority to the factors that impact CC adoption, through the identification of the relative importance of every factor. PLS-SEM determines linear association and ANN determines nonlinear association among predictors and target variables. According to the claim by past scholars, ANN is more accurate in prediction than PLS-SEM $[45,66,169]$. However, this study recognized that conventional statistical approaches are valid and necessary; thereby offering a powerful foundation in previous IS adoption studies. The suggestion of this research is the need to reinterpret past works on IS adoption through the combination of linear and non-linear approaches in order to provide outstanding strength to technology adoption.

\subsection{Practical Implications}

\subsubsection{Implications for Practitioners and Cloud Providers}

HEIs are a promising market for cloud service providers. Hence, this study is remarkably impactful for cloud providers and technology practitioners as it will help in the recognition of the factors that influence the adoption of CC. The research results show the essentiality of compatibility, competitive pressure, complexity, cost saving, security, technology readiness, and top management support in adopting CC in HEIs. CC is a new technology and remains thought-out as disruptive. HEIs still lack awareness of the benefits of using cloud services, especially in developing nations. Hence, cloud providers need to consider a variety of approaches in increasing the understanding of HEIs for this technology via workshops and seminars. There is a need to emphasize functional utilities and simple interfaces in the design of cloud services for HEIs towards easy usage of these services, even with little technological knowledge. Likewise, cloud providers need to provide a clear instruction or navigation system in guiding users in HEIs to operate the services smoothly, thereby increasing the assurance that cloud technology is used.

\subsubsection{Implications for Decision-Makers}

This study emphasizes that top management and ICT department support are important in adopting CC at the HEIs. Likewise, it was discovered that enhancing situations like technology readiness and security with the process in place is the impactful antecedent of adopting CC in HEIs. Hence, there is a need for decision-makers to concentrate on the development of these organizational resources towards gaining the highest merits of cloud services. Besides, top managers pay more attention to the assessment of cloud technology and its assimilation into IT infrastructure effectively and efficiently. In summary, the research results will help decision-makers with the assessment of cloud technology, organization, and environments during the decision of the adoption of CC. Furthermore, decision-makers may use this proposed framework for the investigation of other IT/IS adoption procedures.

\section{Conclusions, Limitations and Future Research Directions}

This current study utilized the notion of adopting CC in HEIs and likewise assessed how the research model created from the DOI mode and TOE framework correlates. This study demonstrates that there is consistency between the proposed model and the data. Apart from the direct influence of vendor support on the intention of adopting CC, the basic factors on decision-makers' intention have a significant influence on the adoption of CC in HEIs. The study outputs have theoretical effects on the identification of the factors influencing the decision-makers' intention to adopt CC and the crucial function of managerial awareness and competitive edges in the research model. The results of the 
current study affirmed that technology readiness is the most remarkable factor that determines the intention to adopt CC. Therefore, the results suggest that technology readiness has a remarkable and direct correlation regarding the adoption of CC in HEIs. Therefore, the results of the study were able to demonstrate that the theories are useful for pro-environmental behavior and to forecast the intention of adopting CC. Besides, the research model is useful for the improved explanation of the intention of decision-makers in adopting CC.

This study has some limitations that will bring about the focus of subsequent research. First, data were collected only in Malaysia. Therefore, subsequent studies can use data from other nations for the validation of the results in the current study. Second, the development of the model in this study was carried out using some critical factors within TOE framework dimensions; hence, future studies may include other critical factors within the three major dimensions. Third, one-time cross-sectional data was used in testing the model, so subsequent studies may work on the validation of the model introduced here with longitudinal data within some time. Fourth, this study tried the investigation of CC adoption in HEIs, based on the context of decision-makers; hence, subsequent studies can pay attention to the context of the cloud provider for a wider comprehension of the intention to adopt CC. Finally, this study looked into only the intent of an organization in adopting CC from the perspective of HEIs. Future studies can use the evaluation of the post-adoption phase, and the successful establishment of this common technology.

A world with current modern technologies that keep evolving requires organizations and individuals to keep adapting to the evolved technologies. Thus, researchers are required to always remain ahead of these innovations by investigating future technologies. In this regard, the fourth industrial (IR 4.0) revolution provides a dialectical, intricate, and intriguing opportunity to higher education (HE 4.0), in which the society would be changed for the better. Education in the IR 4.0 era (Education 4.0) is driven by biller technologies as artificial intelligence (AI), augmented reality (AR), internet of things (IoT), big data analysis, CC, and mobile devices, which can promote a way of teaching, research, and service and change the work area from task-centered to human-based [198]. To the best of the researchers' knowledge, no empirical study has been revealed on the adoption and use of HE 4.0. Therefore, further investigations on the adoption and use of HE 4.0 may gain the attention of the researchers.

Author Contributions: Conceptualization, Y.A.M.Q. and R.A. (Rusli Abdulah); Data curation, Y.A.M.Q. and M.A.A.-S.; Formal analysis, S.A.; Methodology, Y.A.M.Q. and S.A.; Project administration, R.A. (Rusli Abdulah), Y.Y. and R.A. (Rodziah Atan); Resources, Y.Y. and A.A.Y.; Supervision, R.A. (Rusli Abdulah) and R.A. (Rodziah Atan); Validation, M.A.A.-S.; Writing—original draft, Y.A.M.Q.; Writing-review \& editing, A.A.Y. All authors have read and agreed to the published version of the manuscript.

Funding: This research was funded by Research Management Center (RMC), Universiti Putra Malaysia (UPM), grant number 95223100 .

Conflicts of Interest: The authors declare no conflict of interest. 


\section{Appendix A}

Table A1. Factors' Items and Definition

\begin{tabular}{|c|c|c|c|c|c|}
\hline \multirow{2}{*}{ Factors } & \multicolumn{2}{|l|}{ Definitions } & \multicolumn{3}{|l|}{ Measurement Items } \\
\hline & Definition & Source(s) & Items & Adapted Source & Previous Studies \\
\hline CC Adoption (CCA) & $\begin{array}{l}\text { The intention to adopt cloud } \\
\text { computing services in higher } \\
\text { education institutions. }\end{array}$ & & $\begin{array}{l}\text { (1 = Strongly Disagree to } 7=\text { Strongly Agree) } \\
\text { CCA1. My institution intends to continue using our cloud computing solutions rather } \\
\text { than discontinue. } \\
\text { CCA2. My intentions are to continue using our cloud computing service rather than use } \\
\text { any alternative means (traditional software). } \\
\text { CCA3. If I could, I would like to discontinue my use of our cloud computing service. } \\
\text { (reverse coded). }\end{array}$ & [199] & {$[114,115]$} \\
\hline Compatibility (CT) & $\begin{array}{l}\text { The extent to which the value of } \\
\text { the cloud computing is consistent } \\
\text { with existing values, beliefs, } \\
\text { and the needs of a potential } \\
\text { adopter. }\end{array}$ & {$[44,103,165,200]$} & $\begin{array}{l}\text { CT1. The continuous use of cloud computing will be compatible with all aspects of my } \\
\text { institution work. } \\
\text { CT2. The continuous use of cloud computing fits well with the way I like to work at } \\
\text { the institution. } \\
\text { CT3. The continuous use of cloud computing is completely compatible with my current } \\
\text { work requirements at the institution. } \\
\text { CT4. It is easy to integrate cloud computing with our other existing systems (e.g., LMS, } \\
\text { Finance, ERP, CRM, SCM, etc.). } \\
\text { CT5. Cloud computing is compatible with our culture and values. }\end{array}$ & {$[83,94,112,160]$} & {$[31,84,133,134,161]$} \\
\hline Complexity (CX) & $\begin{array}{l}\text { The degree of difficulty to } \\
\text { understand, use, or continue } \\
\text { using the cloud computing. }\end{array}$ & {$[44,103,201]$} & $\begin{array}{l}\text { Cx1. The continuous use of cloud computing requires a lot of mental effort. } \\
\text { Cx2. The continuous use of cloud computing is frustrating. } \\
\text { Cx3. The continuous use of cloud computing is too complex. } \\
\text { Cx4. The skills needed to continue using cloud computing are too complex for the users. }\end{array}$ & {$[83,126]$} & {$[31,94,133]$} \\
\hline Security (SC) & $\begin{array}{l}\text { The degree to which cloud } \\
\text { computing is appropriate for } \\
\text { HEIs systems security } \\
\text { requirements. }\end{array}$ & {$[44,202,203]$} & $\begin{array}{l}\text { SC1. The confidentiality and security of my institution data are guaranteed when using } \\
\text { cloud computing solutions. } \\
\text { SC2. In case of damage, present liability law is clear about who will bear the liability. } \\
\text { SC3. The cloud computing service provider will not exploit contractual loopholes } \\
\text { (i.e., incomplete contracting) to the detriment of my institution. } \\
\text { SC4. The institution's data stored on cloud computing is secure. } \\
\text { SC5. The institution's data will be adequately protected through cloud computing systems. } \\
\text { SC6. Cloud computing providers have stronger security systems to safeguard the } \\
\text { institution's data. }\end{array}$ & [204] & {$[83,84,112,205,206]$} \\
\hline $\begin{array}{l}\text { Technology Readiness } \\
\text { (TR) }\end{array}$ & $\begin{array}{l}\text { The technological characteristics } \\
\text { available in the institution, such } \\
\text { as the IT professionals and the IT } \\
\text { infrastructure. }\end{array}$ & {$[83,85]$} & $\begin{array}{l}\text { TR1. My institution knows how cloud computing can be used to support our operations. } \\
\text { TR2. The technology infrastructure of my institution is available to support cloud } \\
\text { computing for continuous use. } \\
\text { TR3. My institution is dedicated to ensuring that the users are familiar with } \\
\text { cloud computing. } \\
\text { TR4. My institution has good knowledge of cloud computing. }\end{array}$ & [93] & {$[83,84]$} \\
\hline
\end{tabular}


Table A1. Cont.

\begin{tabular}{|c|c|c|c|c|c|}
\hline \multirow{2}{*}{ Factors } & \multicolumn{2}{|l|}{ Definitions } & \multicolumn{3}{|l|}{ Measurement Items } \\
\hline & Definition & Source(s) & Items & Adapted Source & Previous Studies \\
\hline Cost saving (CS) & $\begin{array}{l}\text { Cloud computing creates an } \\
\text { opportunity for innovation, } \\
\text { reduces infrastructure costs, } \\
\text { decreases energy consumption, } \\
\text { and lowers maintenance } \\
\text { expenditures. }\end{array}$ & {$[84,207,208]$} & $\begin{array}{l}\text { CS1. Cloud computing is more effective than the alternative. } \\
\text { CS2. Cloud computing saves time and effort. } \\
\text { CS3. Institutions can avoid unnecessary cost and time by continuous use of } \\
\text { cloud computing. }\end{array}$ & [93] & {$[83,84]$} \\
\hline $\begin{array}{l}\text { Top Management } \\
\text { Support (TMS) }\end{array}$ & $\begin{array}{l}\text { The vision, support, } \\
\text { and commitment provided to } \\
\text { foster the desired environment } \\
\text { for the continuous adoption of } \\
\text { cloud computing in HEIs. }\end{array}$ & {$[83,209]$} & $\begin{array}{l}\text { TMS1. Top management is likely to take risk involving the continuous use of } \\
\text { cloud computing. } \\
\text { TMS2. Top management actively participates in establishing a vision and formulating } \\
\text { strategies for the continuous use of cloud computing. } \\
\text { TMS3. Top management communicates its support for the continuous use of cloud } \\
\text { computing. }\end{array}$ & [93] & {$[83,84]$} \\
\hline $\begin{array}{l}\text { Competitive Pressure } \\
\text { (CP) }\end{array}$ & $\begin{array}{l}\text { The pressure perceived by an } \\
\text { institution's leaders that } \\
\text { competitors have achieved } \\
\text { substantial competitive } \\
\text { advantage by using cloud } \\
\text { computing services (for example, } \\
\text { in terms of teaching and learning } \\
\text { effectiveness). }\end{array}$ & {$[114,129,130]$} & $\begin{array}{l}\text { CP1. More and more institutions are conducting teaching activities and communication } \\
\text { through cloud computing. } \\
\text { CP2. More and more institutions are conducting knowledge management and sharing } \\
\text { though cloud computing. } \\
\text { CP3. More and more institutions are conducting project and learning management though } \\
\text { cloud computing. }\end{array}$ & {$[85,112]$} & [114] \\
\hline $\begin{array}{l}\text { Vendor Support } \\
\text { (VS) }\end{array}$ & $\begin{array}{l}\text { Refers to the supplier activities } \\
\text { that can significantly influence } \\
\text { the probability to continue using } \\
\text { cloud computing }\end{array}$ & [210] & $\begin{array}{l}\text { VS1. Vendors actively market cloud computing. } \\
\text { VS2. There is a service level agreement (SLA), guaranteed by the vendor. } \\
\text { VS3. There is adequate technical support for cloud computing provided by vendors. } \\
\text { VS4. Support is easily available from cloud computing vendors during implementation. } \\
\text { VS5. Training for cloud computing is adequately provided by vendors. }\end{array}$ & {$[160,167,211]$} & {$[134,167]$} \\
\hline
\end{tabular}




\section{References}

1. Moscato, F.; Aversa, R.; Di Martino, B.; Petcu, D.; Rak, M. An Ontology for the Cloud in mOSAIC. In Cloud Computing; CRC Press: Boca Raton, FL, USA, 2017; pp. 467-485.

2. IDC. IDC Forecasts Worldwide Public Cloud Services Spending. Available online: https://www.idc.com/ getdoc.jsp? containerId=prUS44891519 (accessed on 17 June 2020).

3. Qasem, Y.A.M.; Abdullah, R.; Jusoh, Y.Y.; Atan, R.; Asadi, S. Cloud Computing Adoption in Higher Education Institutions: A Systematic Review. IEEE Access 2019, 7, 63722-63744. [CrossRef]

4. Sayuti, Y.; Albattat, A.; Ariffin, A.N.; Nazrin, N.S.; Silahudeen, T. Food safety knowledge, attitude and practices among management and science university students, Shah Alam. Manag. Sci. Lett. 2020, 10, 929-936. [CrossRef]

5. AlAjmi, Q.; Arshah, R.A.; Kamaludin, A.; Sadiq, A.S.; Al-Sharafi, M. A conceptual model of e-learning based on cloud computing adoption in higher education institutions. In Proceedings of the 2017 International Conference on Electrical and Computing Technologies and Applications (ICECTA), Aurak, UAE, 21-23 November 2017.

6. Abdullah, R.; Eri, Z.D.; Talib, A.M. A model of knowledge management system for facilitating knowledge as a service (KaaS) in cloud computing environment. In Proceedings of the 2011 International Conference on Research and Innovation in Information Systems (ICRIIS, 2011), Kuala Lumpur, Malaysia, 23-24 November 2011; IEEE: Piscataway, NJ, USA, 2011.

7. Monroy, C.R.; Arias, C.A.; Guerrero, Y.N. The new cloud computing paradigm: The way to IT seen as a utility. Lat. Am. Caribb. J. Eng. Educ. 2012, 6, 24-31.

8. Thomas, P.Y. Cloud computing: A potential paradigm for practising the scholarship of teaching and learning. Electron. Libr. 2011, 29, 214-224. [CrossRef]

9. Razak, S.F.A. Cloud computing in Malaysia Universities. In Proceedings of the 2009 Innovative Technologies in Intelligent Systems and Industrial Applications, Kuala Lumpur, Malaysia, 25-26 July 2009.

10. Abdullah, R.; Alsharaei, Y.A. A Mobile Knowledge as a service (mKaaS) model of knowledge management system in facilitating knowledge sharing of cloud education community environment. In Proceedings of the 2016 Third International Conference on Information Retrieval and Knowledge Management (CAMP), Melaka, Malaysia, 23-24 August 2016; IEEE: PIscataway, NJ, USA, 2016.

11. Qasem, Y.A.; Abdullah, R.; Atan, R.; Jusoh, Y.Y. Towards Developing A Cloud-Based Education As A Service (CEAAS) Model For Cloud Computing Adoption In Higher Education Institutions. Complexity 2018, 6, 7. [CrossRef]

12. Njenga, K.; Garg, L.; Bhardwaj, A.K.; Prakash, V.; Bawa, S. The cloud computing adoption in higher learning institutions in Kenya: Hindering factors and recommendations for the way forward. Telemat. Inf. 2019, 38, 225-246. [CrossRef]

13. Rahimah, K.; Aziati, N. The Integrated Framework of Cloud Computing Implementation in Higher Education Institution: A Review of Literature. Adv. Sci. Lett. 2017, 23, 1475-1479. [CrossRef]

14. Shakeabubakor, A.A.; Sundararajan, E.; Hamdan, A.R. Cloud Computing Services and Applications to Improve Productivity of University Researchers. Int. J. Inf. Electron. Eng. 2015, 5, 153. [CrossRef]

15. Rahman, M.M.; Suhaimi, A.; Shah, A. A Model of Factors Influencing Cloud Computing Adoption Among Faculty Members and Students of Higher Educational Institutions of Bangladesh. In Proceedings of the 2018 IEEE 5th International Conference on Engineering Technologies and Applied Sciences (ICETAS), Bangkok, Thailand, 22-23 November 2018; IEEE: Piscataway, NJ, USA, 2018.

16. Odeh, M.; Garcia-Perez, A.; Warwick, K. Cloud computing adoption at higher education institutions in developing countries: A qualitative investigation of main enablers and barriers. Int. J. Inf. Educ. Technol. 2017, 7, 921-927. [CrossRef]

17. Wilson, B. A Framework to Support Cloud Adoption Decision-Making by SMEs in Tamil Nadu. Ph.D. Thesis, Sheffield Hallam University, Sheffield, UK, 2017.

18. Alharthi, A.; Alassafi, M.O.; Walters, R.J.; Wills, G.B. An exploratory study for investigating the critical success factors for cloud migration in the Saudi Arabian higher education context. Telemat. Inf. 2017, 34, 664-678. [CrossRef]

19. Alexander, B. Social networking in higher education. In The Tower and the Cloud; EDUCAUSE: Louisville, CO, USA, 2008; pp. 197-201. 
20. Katz, N. The Tower and the Cloud. Higher Education in the Age of Cloud Computing; EDUCAUSE: Louisville, CO, USA, 2008; p. 9.

21. Sultan, N. Cloud computing for education: A new dawn? Int. J. Inf. Manag. 2010, 30, 109-116. [CrossRef]

22. Arpaci, I. Antecedents and consequences of cloud computing adoption in education to achieve knowledge management. Comput. Hum. Behav. 2017, 70, 382-390. [CrossRef]

23. Vaquero, L.M. EduCloud: PaaS versus IaaS Cloud Usage for an Advanced Computer Science Course. IEEE Trans. Educ. 2011, 54, 590-598. [CrossRef]

24. Ashtari, S.; Eydgahi, A. Student perceptions of cloud applications effectiveness in higher education. J. Comput. Sci. 2017, 23, 173-180. [CrossRef]

25. Katz, R.; Goldstein, P.; Yanosky, R. Cloud Computing in Higher Education. In EDUCAUSE. 2010. Available online: http://net.educause.edu/section_params/conf/CCW (accessed on 5 October 2010).

26. Commander, S.; Harrison, R.; Menezes-Filho, N. ICT and productivity in developing countries: New firm-level evidence from Brazil and India. Rev. Econ. Stat. 2011, 93, 528-541. [CrossRef]

27. Javaid, M.; Haleem, A.; Vaishya, R.; Bahl, S.; Suman, R.; Vaish, A. Industry 4.0 technologies and their applications in fighting COVID-19 pandemic. Diabetes Metab. Syndr. Clin. Res. Rev. 2020, 14, 419-422. [CrossRef]

28. Toquero, C. Challenges and Opportunities for Higher Education amid the COVID-19 Pandemic: The Philippine Context. Pedagog. Res. 2020, 5, 1-5. [CrossRef]

29. Walther, S.; Sedera, D.; Urbach, N.; Eymann, T.; Otto, B.; Sarker, S. Should we stay, or should we go? Analyzing continuance of cloud enterprise systems. J. Inf. Technol. Theory Appl. 2018, 19, 57-88.

30. Sabi, H.M.; Uzoka, F.; Langmia, K.; Njeh, K. Conceptualizing a model for adoption of cloud computing in education. Int. J. Inf. Manag. 2016, 36, 183-191. [CrossRef]

31. Sabi, H.M.; Uzoka, F.; Langmia, K.; Njeh, F.; Tsuma, C. A cross-country model of contextual factors impacting cloud computing adoption at universities in sub-Saharan Africa. Inf. Syst. Front. 2018, 20, 1381-1404. [CrossRef]

32. Dahiru, A.A.; Bass, J.M.; Allison, I.K. Cloud computing adoption in sub-Saharan Africa: An analysis using institutions and capabilities. In Proceedings of the International Conference on Information Society, i-Society 2014, London, UK, 10-12 November 2014.

33. Md Kassim, S.S.; Salleh, M.; Zainal, A. Cloud Computing: A General User's Perception and Security Awareness in Malaysian Polytechnic. In Pattern Analysis, Intelligent Security and the Internet of Things; Abraham, A., Muda, A.K., Choo, Y.-H., Eds.; Springer International Publishing: Cham, Switzerland, 2015; pp. 131-140.

34. Asadi, S.; Yadegaridehkordi, E. Customers perspectives on adoption of cloud computing in banking sector. Inf. Technol. Manag. 2017, 18, 305-330. [CrossRef]

35. Tashkandi, A.N.; Al-Jabri, I.M. Cloud computing adoption by higher education institutions in Saudi Arabia: An exploratory study. Clust. Comput. 2015, 18, 1527-1537. [CrossRef]

36. Shi, Y.; Yang, H.; Yang, Z.; Wu, D. Trends of Cloud Computing in Education, in Hybrid Learning. Theory and Practice. In Proceedings of the 7th International Conference, ICHL 2014, Shanghai, China, 8-10 August 2014; Simon, K.S.C., Fong, J., Zhang, J., Kwan, R., Eds.; Springer International Publishing: Cham, Switzerland, 2014; pp. 116-128.

37. Yuvaraj, M. Determining factors for the adoption of cloud computing in developing countries: A case study of Indian academic libraries. Bottom Line 2016, 29, 259-272. [CrossRef]

38. Yuvaraj, M. Problems and prospects of implementing cloud computing in university libraries: A case study of Banaras Hindu University library system. Libr. Rev. 2015, 64, 567-582. [CrossRef]

39. Surya, G.S.F.; Fajar, S.; Surendro, K. E-Readiness Framework for Cloud Computing Adoption in Higher Education. In Proceedings of the 2014 International Conference of Advanced Informatics: Concept, Theory and Application (ICAICTA), Bandung, Indonesia, 20-21 August 2014; IEEE: Piscataway, NJ, USA, 2014; pp. 278-282.

40. Lal, P. Organizational learning management systems: Time to move learning to the cloud! Dev. Learn. Organ. 2015, 29, 13-15. [CrossRef]

41. Koch, F.; Assunção, M.D.; Cardonha, C.; Netto, M.A. Optimising resource costs of cloud computing for education. Future Gener. Comput. Syst. 2016, 55, 473-479. [CrossRef]

42. Petković, D. Prediction of laser welding quality by computational intelligence approaches. Optik 2017, 140, 597-600. [CrossRef] 
43. Tornatzky, L.G.; Fleischer, M.; Chakrabarti, A.K. Processes of Technological Innovation; Lexington Books: Lexington, MA, USA, 1990.

44. Rogers Everett, M. Diffusion of Innovations; The Free Press: New York, NY, USA, 1995; p. 12.

45. Scott, J.E.; Walczak, S. Cognitive engagement with a multimedia ERP training tool: Assessing computer self-efficacy and technology acceptance. Inf. Manag. 2009, 46, 221-232. [CrossRef]

46. Al-Sharafi, M.A.; Arshah, R.A.; Abu-Shanab, E.A. Factors Influencing the Continuous Use of Cloud Computing Services in Organization Level. In Proceedings of the International Conference on Advances in Image Processing-ICAIP 2017, Bangkok, Thailand, 25-27 August 2017; pp. 189-194.

47. Mell, P.; Grance, T. The NIST Definition of Cloud Computing; U.S. Department of Commerce, National Institute of Standards and Technology: Gaithersburg, MD, USA, 2011.

48. Jing, S.-Y.; Ali, S.; She, K.; Zhong, Y. State-of-the-art research study for green cloud computing. J. Supercomput. 2013, 65, 445-468. [CrossRef]

49. Zissis, D.; Lekkas, D. Addressing cloud computing security issues. Future Gener. Comput. Syst. 2012, 28, 583-592. [CrossRef]

50. Beloglazov, A.; Abawajy, J.; Buyya, R. Energy-aware resource allocation heuristics for efficient management of data centers for cloud computing. Future Gener. Comput. Syst. 2012, 28, 755-768. [CrossRef]

51. Dillon, T.; Wu, C.; Chang, E. Cloud computing: Issues and challenges. In Proceedings of the 2010 24th IEEE International Conference on Advanced Information Networking and Applications (AINA), Perth, WA, Australia, 20-23 April 2010; IEEE: Piscataway, NJ, USA, 2010.

52. Qasim, A.; Sadiq, A.; Kamaludin, A.; Al-Sharafi, M. E-learning models: The effectiveness of the cloud-based E-learning model over the traditional E-learning model. In Proceedings of the 2017 8th International Conference on Information Technology (ICIT), Amman, Jordan, 17-18 May 2017; IEEE: Piscataway, NJ, USA, 2017.

53. Thorsteinsson, G.; Page, T.; Niculescu, A. Using virtual reality for developing design communication. Stud. Inf. Control 2010, 19, 93-106. [CrossRef]

54. Pocatilu, P.; Alecu, F.; Vetrici, M. Using cloud computing for E-learning systems. In Proceedings of the 8th WSEAS International Conference on Data Networks, Communications, Computers, Baltimore, MD, USA, 7-9 November 2009; World Scientific and Engineering Academy and Society (WSEAS): Athens, Greece, 2009.

55. Sasikala, S.; Prema, S. Massive Centralized Cloud Computing (MCCC) Exploration in Higher Education. 2011. Available online: http://14.139.186.108/jspui/handle/123456789/1528 (accessed on 30 May 2020).

56. Qasem, Y.A.; Abdullah, R.; Atan, R.; Jusoh, Y. Mapping and Analyzing Process of Cloud-based Education as a Service (CEaaS) Model for Cloud Computing Adoption in Higher Education Institutions. In Proceedings of the 2018 Fourth International Conference on Information Retrieval and Knowledge Management (CAMP 2018), Sabah, Malaysia, 26-28 March 2018; IEEE: Piscataway, NJ, USA, 2018.

57. Al-Sharafi, M.A.; Arshah, R.A.; Abu-Shanab, E.A. Factors affecting the continuous use of cloud computing services from expert's perspective. In Proceedings of the TENCON 2017 IEEE Region 10 Conference, Penang, Malaysia, 5-8 November 2017.

58. Alajmi, Q.A.; Kamaludin, A.; Arshah, R.A.; Al-Sharafi, M.A. The Effectiveness of Cloud-Based E-Learning towards Quality of Academic Services: An Omanis' Expert View. Int. J. Adv. Comput. Sci. Appl. 2018, 9, 158-164. [CrossRef]

59. Militaru, G.; Purcărea, A.A.; Negoiţă, O.D.; Niculescu, A. Examining Cloud Computing Adoption Intention in Higher Education: Exploratory Study. In Proceedings of the International Conference on Exploring Services Science 2016, Bucharest, Romania, 25-27 May 2016; Springer: Cham, Switzerland, 2016.

60. Bhatiasevi, V.; Naglis, M. Investigating the structural relationship for the determinants of cloud computing adoption in education. Educ. Inf. Technol. 2016, 21, 1197-1223. [CrossRef]

61. Almazroi, A.A.; Shen, H.; Teoh, K.K.; Babar, M.A. Cloud for e-Learning: Determinants of Its Adoption by University Students in a Developing Country. In Proceedings of the 2016 IEEE 13th International Conference on e-Business Engineering (ICEBE), Macau, China, 4-6 November 2016; IEEE: Piscataway, NJ, USA, 2016.

62. Hwang, B.-N.; Huang, C.-Y.; Yang, C.-L. Determinants and their causal relationships affecting the adoption of cloud computing in science and technology institutions. Innovation 2016, 18, 164-190. [CrossRef]

63. Behrend, T.S.; Wiebe, E.N.; London, J.E.; Johnson, E.C. Cloud computing adoption and usage in community colleges. Behav. Inf. Technol. 2011, 30, 231-240. [CrossRef] 
64. Li, Y.-H. An empirical investigation on the determinants of e-procurement adoption in Chinese manufacturing enterprises. In 2008 International Conference on Management Science and Engineering 15th Annual Conference Proceedings; IEEE: Piscataway, NJ, USA, 2008.

65. Shiau, W.L.; Chau, P.K. Understanding behavioral intention to use a cloud computing classroom: A multiple model comparison approach. Inf. Manag. 2016, 53, 355-365. [CrossRef]

66. Sharma, S.K.; Al-Badi, A.; Govindaluri, S.M.; Alkharusi, M. Predicting motivators of cloud computing adoption: A developing country perspective. Comput. Hum. Behav. 2016, 62, 61-69. [CrossRef]

67. Gurung, R.K.; Alsadoon, A.; Prasad, P.W.C.; Elchouemi, A. Impacts of Mobile Cloud Learning (MCL) on Blended Flexible Learning (BFL). In Proceedings of the 2016 International Conference on Information and Digital Technologies (IDT) 2016, Rzeszów, Poland, 5-7 July 2016.

68. Arpaci, I. Understanding and predicting students' intention to use mobile cloud storage services. Comput. Hum. Behav. 2016, 58, 150-157. [CrossRef]

69. Tan, X.; Kim, Y. User acceptance of SaaS-based collaboration tools: A case of Google Docs. J. Enterp. Inf. Manag. 2015, 28, 423-442. [CrossRef]

70. Arpaci, I.; Kilicer, K.; Bardakci, S. Effects of security and privacy concerns on educational use of cloud services. Comput. Hum. Behav. 2015, 45, 93-98. [CrossRef]

71. Yadegaridehkordi, E.; Iahad, N.A.; Ahmad, N. Task-Technology Fit Assessment of Cloud-Based Collaborative Learning Technologies. Remote Work and Collaboration: Breakthroughs in Research and Practice: Breakthroughs in Research and Practice. Int. J. Inf. Syst. Serv. Sect. (IJISSS) 2016, 8, 58-73. [CrossRef]

72. Stantchev, V.; Colomo-Palacios, R.; Soto-Acosta, P.; Misra, M. Learning management systems and cloud file hosting services: A study on students' acceptance. Comput. Hum. Behav. 2014, 31, 612-619. [CrossRef]

73. Pinheiro, P.; Aparicio, M.; Costa, C. Adoption of cloud computing systems. In Proceedings of the 2014 International Conference on Information Systems and Design of Communication, Lisbon, Portugal, 16-17 May 2014; ACM Digital Library: New York, NY, USA, 2014; pp. 127-131.

74. Nguyen, T.D.; Nguyen, T.M.; Pham, Q.-T.; Misra, S. Acceptance and Use of E-Learning Based on Cloud Computing: The Role of Consumer Innovativeness. In Computational Science and Its Applications-ICCSA 2014; Murgante, B., Misra, S., Rocha, A.M.A.C., Torre, C., Rocha, J.G., Eds.; Springer: Cham, Switzerland, 2014; Volume Pt V, pp. 159-174.

75. Atchariyachanvanich, K.; Siripujaka, N.; Jaiwong, N. What Makes University Students Use Cloud-based E-Learning? Case Study of KMITL Students. In Proceedings of the 2014 International Conference on Information Society (I-Society 2014), London, UK, 12 November 2014; pp. 112-116.

76. Wu, W.W.; Lan, L.W.; Lee, Y.T. Factors hindering acceptance of using cloud services in university: A case study. Electron. Libr. 2013, 31, 84-98. [CrossRef]

77. Park, S.C.; Ryoo, S.Y. An empirical investigation of end-users' switching toward cloud computing: A two factor theory perspective. Comput. Hum. Behav. 2013, 29, 160-170. [CrossRef]

78. Oliveira, T.; Martins, M.F. Literature review of information technology adoption models at firm level. Electron. J. Inf. Syst. Eval. 2011, 14, 110-121.

79. Leinbach, T.R. Global E-Commerce: Impacts of National Environment and Policy; Kraemer, K.L., Dedrick, J., Melville, N.P., Zhu, K., Eds.; Cambridge University Press: Cambridge, UK, 2006; p. xxii+444. ISBN 0-521-84822-9.

80. Lin, H.-F.; Lin, S.-M. Determinants of e-business diffusion: A test of the technology diffusion perspective. Technovation 2008, 28, 135-145. [CrossRef]

81. Ramdani, B.; Kawalek, P.; Lorenzo, O. Predicting SMEs' adoption of enterprise systems. J. Enterp. Inf. Manag. 2009, 22, 10-24. [CrossRef]

82. Mohammed, F.; Ibrahim, O.; Nilashi, M.; Alzurqa, E.A. Cloud computing adoption model for e-government implementation. Inf. Dev. 2017, 33, 303-323. [CrossRef]

83. Martins, R.; Oliveira, T.; Thomas, M.A. An empirical analysis to assess the determinants of SaaS diffusion in firms. Comput. Hum. Behav. 2016, 62, 19-33. [CrossRef]

84. Oliveira, T.; Thomas, M.; Espadanal, M. Assessing the determinants of cloud computing adoption: An analysis of the manufacturing and services sectors. Inf. Manag. 2014, 51, 497-510. [CrossRef]

85. Zhu, K.; Kraemer, K.L. Post-adoption variations in usage and value of e-business by organizations: Cross-country evidence from the retail industry. Inf. Syst. Res. 2005, 16, 61-84. [CrossRef] 
86. Oliveira, T.; Martins, M.F. Understanding e-business adoption across industries in European countries. Ind. Manag. Data Syst. 2010, 110, 1337-1354. [CrossRef]

87. Zmud, R.W. Diffusion of modern software practices: Influence of centralization and formalization. Manag. Sci. 1982, 28, 1421-1431. [CrossRef]

88. Borgman, H.P.; Bahli, B.; Heier, H.; Schewski, F. Cloudrise: Exploring cloud computing adoption and governance with the TOE framework. In Proceedings of the 2013 46th Hawaii International Conference on System Sciences (HICSS), Maui, HI, USA, 7-10 January 2013; IEEE: Piscataway, NJ, USA, 2013.

89. Gangwar, H.; Date, H.; Ramaswamy, R. Understanding determinants of cloud computing adoption using an integrated TAM-TOE model. J. Enterp. Inf. Manag. 2015, 28, 107-130. [CrossRef]

90. Reza Bazi, H.; Hassanzadeh, A.; Moeini, A. A comprehensive framework for cloud computing migration using Meta-synthesis approach. J. Syst. Softw. 2017, 128, 87-105. [CrossRef]

91. Baker, J. The technology-organization-environment framework. In Information Systems Theory; Springer: New York, NY, USA, 2012; pp. 231-245.

92. Bose, R.; Luo, X. Integrative framework for assessing firms' potential to undertake Green IT initiatives via virtualization-A theoretical perspective. J. Strateg. Inf. Syst. 2011, 20, 38-54. [CrossRef]

93. Chan, F.T.; Chong, A.Y.-L. Determinants of mobile supply chain management system diffusion: A structural equation analysis of manufacturing firms. Int. J. Prod. Res. 2013, 51, 1196-1213. [CrossRef]

94. Chong, A.Y.-L.; Chan, F.T. Structural equation modeling for multi-stage analysis on Radio Frequency Identification (RFID) diffusion in the health care industry. Expert Syst. Appl. 2012, 39, 8645-8654. [CrossRef]

95. Kim, S.; Garrison, G. Understanding users' behaviors regarding supply chain technology: Determinants impacting the adoption and implementation of RFID technology in South Korea. Int. J. Inf. Manag. 2010, 30, 388-398. [CrossRef]

96. Wang, Y.-M.; Wang, Y.-S.; Yang, Y.-F. Understanding the determinants of RFID adoption in the manufacturing industry. Technol. Forecast. Soc. Chang. 2010, 77, 803-815. [CrossRef]

97. Thomas, M.; Costa, D.; Oliveira, T. Assessing the role of IT-enabled process virtualization on green IT adoption. Inf. Syst. Front. 2016, 18, 693-710. [CrossRef]

98. Venkatesh, V.; Bala, H. Adoption and impacts of interorganizational business process standards: Role of partnering synergy. Inf. Syst. Res. 2012, 23, 1131-1157. [CrossRef]

99. Zhu, K.; Kraemer, K.; Xu, S. Electronic business adoption by European firms: A cross-country assessment of the facilitators and inhibitors. Eur. J. Inf. Syst. 2003, 12, 251-268. [CrossRef]

100. Zhu, K.; Kraemer, K.L.; Xu, S. The process of innovation assimilation by firms in different countries: A technology diffusion perspective on e-business. Manag. Sci. 2006, 52, 1557-1576. [CrossRef]

101. Yang, Z.; Sun, J.; Zhang, Y.; Wang, Y. Understanding SaaS adoption from the perspective of organizational users: A tripod readiness model. Comput. Hum. Behav. 2015, 45, 254-264. [CrossRef]

102. Abdollahzadegan, A.; Che Hussin, A.R.; Moshfegh Gohary, M.; Amini, M. The organizational critical success factors for adopting cloud computing in SMEs. JISRI 2013, 4, 67-74.

103. Low, C.; Chen, Y.; Wu, M. Understanding the determinants of cloud computing adoption. Ind. Manag. Data Syst. 2011, 111, 1006-1023. [CrossRef]

104. Rogers, E.M. Diffusion of Innovations; Simon and Schuster: New York, NY, USA, 2010.

105. Sharma, M.K. Receptivity of India's small and medium-sized enterprises to information system adoption. Enterp. Inf. Syst. 2009, 3, 95-115. [CrossRef]

106. Shah Alam, S. Adoption of internet in Malaysian SMEs. J. Small Bus. Enterp. Dev. 2009, 16, $240-255$. [CrossRef]

107. Azadegan, A.; Teich, J. Effective benchmarking of innovation adoptions: A theoretical framework for e-procurement technologies. Benchmark. Int. J. 2010, 17, 472-490. [CrossRef]

108. Tsai, M.-C.; Lee, W.; Wu, H.-C. Determinants of RFID adoption intention: Evidence from Taiwanese retail chains. Inf. Manag. 2010, 47, 255-261. [CrossRef]

109. Ifinedo, P. An empirical analysis of factors influencing Internet/e-business technologies adoption by SMEs in Canada. Int. J. Inf. Technol. Decis. Mak. 2011, 10, 731-766. [CrossRef]

110. Chong, A.Y.-L.; Lin, B.; Ooi, K.-B.; Raman, M. Factors affecting the adoption level of c-commerce: An empirical study. J. Comput. Inf. Syst. 2009, 50, 13-22. 
111. Dedrick, J.; West, J. Why firms adopt open source platforms: A grounded theory of innovation and standards adoption. In Proceedings of the Workshop on Standard Making: A Critical Research Frontier for Information Systems, Seattle, WA, USA, 12-14 December 2003.

112. Zhu, K.; Dong, S.; Xu, S.X.; Kraemer, K.L. Innovation diffusion in global contexts: Determinants of post-adoption digital transformation of European companies. Eur. J. Inf. Syst. 2006, 15, 601-616. [CrossRef]

113. Gibbs, J.L.; Kraemer, K.L. A cross-country investigation of the determinants of scope of e-commerce use: An institutional approach. Electron. Mark. 2004, 14, 124-137. [CrossRef]

114. Obal, M. What drives post-adoption usage? Investigating the negative and positive antecedents of disruptive technology continuous adoption intentions. Ind. Mark. Manag. 2017, 63, 42-52. [CrossRef]

115. Jia, Q.; Guo, Y.; Barnes, S.J. Enterprise 2.0 post-adoption: Extending the information system continuance model based on the technology-Organization-environment framework. Comput. Hum. Behav. 2017, 67, 95-105. [CrossRef]

116. Hair, J.F., Jr.; Hult, G.T.M.; Ringle, C.M.; Sarstedt, M. A Primer on Partial Least Squares Structural Equation Modeling (PLS-SEM); Sage Publications: Los Angeles, CA, USA, 2016.

117. Haykin, S. Neural Networks: A Comprehensive Foundation; Prentice Hall: New Dehli, India, 1994.

118. Garson, G.D. Neural Networks: An Introductory Guide for Social Scientists; Sage: London, UK, 1998.

119. Chiang, W.-Y.K.; Zhang, D.; Zhou, L. Predicting and explaining patronage behavior toward web and traditional stores using neural networks: A comparative analysis with logistic regression. Decis. Support Syst. 2006, 41, 514-531. [CrossRef]

120. Kaastra, I.; Boyd, M. Designing a neural network for forecasting financial and economic time series. Neurocomputing 1996, 10, 215-236. [CrossRef]

121. Hsu, C.-I.; Shih, M.L.; Huang, B.W.; Lin, B.Y.; Lin, C.N. Predicting tourism loyalty using an integrated Bayesian network mechanism. Expert Syst. Appl. 2009, 36, 11760-11763. [CrossRef]

122. Asadi, S.; Abdullah, R.; Safaei, M.; Nazir, S. An Integrated SEM-Neural Network Approach for Predicting Determinants of Adoption of Wearable Healthcare Devices. Mob. Inf. Syst. 2019, 2019. [CrossRef]

123. Hu, M.Y.; Shanker, M.; Hung, M.S. Estimation of posterior probabilities of consumer situational choices with neural network classifiers. Int. J. Res. Mark. 1999, 16, 307-317. [CrossRef]

124. Shmueli, G.; Koppius, O.R. Predictive analytics in information systems research. Mis Q. 2011, 35, 553-572. [CrossRef]

125. Sekaran, U.; Bougie, R. Research Methods for Business: A Skill Building Approach; John Wiley \& Sons: Hoboken, NJ, USA, 2016.

126. Moore, G.C.; Benbasat, I. Development of an instrument to measure the perceptions of adopting an information technology innovation. Inf. Syst. Res. 1991, 2, 192-222. [CrossRef]

127. Taweel, A. Examining the Relationship between Technological, Organizational, and Environmental Factors and Cloud Computing Adoption; UMI Dissertations Publishing; ProQuest: Ann Arbor, MI, USA, 2012.

128. Tashkandi, A.; Al-Jabri, I. Cloud Computing Adoption by Higher Education Institutions in Saudi Arabia: Analysis Based on TOE. In Proceedings of the 2015 International Conference on Cloud Computing, ICCC 2015, Riyadh, Saudi Arabia, 26-29 April 2015.

129. Bughin, J.; Chui, M.; Manyika, J. Clouds, big data, and smart assets: Ten tech-enabled business trends to watch. McKinsey Q. 2010, 56, 75-86.

130. Lin, H.-F. Understanding the determinants of electronic supply chain management system adoption: Using the technology-organization-environment framework. Technol. Forecast. Soc. Chang. 2014, 86, 80-92. [CrossRef]

131. Shah Alam, S.; Ali, M.Y.; Jani, M.F.M. An empirical study of factors affecting electronic commerce adoption among SMEs in Malaysia. J. Bus. Econ. Manag. 2011, 12, 375-399. [CrossRef]

132. Wang, M.W.; Lee, O.-K.; Lim, K.L. Knowledge management systems diffusion in Chinese enterprises: A multi-stage approach with the technology-organization-environment framework. In Proceedings of the 2007 Pacific Asia Conference on Information Systems (PACIS), Auckland, New Zealand, 4-6 July 2007; p. 70.

133. Ifinedo, P. Internet/e-business technologies acceptance in Canada's SMEs: An exploratory investigation. Internet Res. 2011, 21, 255-281. [CrossRef]

134. Klug, W.; Bai, X. The determinants of cloud computing adoption by colleges and universities. Int. J. Bus. Res. Inf. Technol. 2015, 2, 14-30. 
135. Tornatzky, L.G.; Klein, K.J. Innovation characteristics and innovation adoption-implementation: A meta-analysis of findings. IEEE Trans. Eng. Manag. 1982, 1, 28-45. [CrossRef]

136. Opala, O.J. An Analysis of Security, Cost-Effectiveness, and it Compliance Factors Influencing Cloud Adoption by it Managers. Ph.D. Thesis, Capella University, Minneapolis, MN, USA, 2012.

137. Broberg, J.; Buyya, R.; Tari, Z. Creating aCloud Storage'Mashup for High Performance, Low Cost Content Delivery, Service-Oriented Computing-ICSOC 2008 Workshops. In Proceedings of the International Conference on Service-Oriented Computing ICSOC 2008 International Workshops, Sydney, Australia, 1 December 2008; Springer: Berlin/Heidelberg, Germany, 2008.

138. Mircea, M. SOA, BPM and cloud computing: Connected for innovation in higher education. In Proceedings of the 2010 International Conference on Education and Management Technology, Cario, Egypt, 2-4 November 2010; IEEE: Piscataway, NJ, USA, 2010.

139. Saya, S.; Pee, L.G.; Kankanhalli, A. “THE IMPACT OF INSTITUTIONAL INFLUENCES ON PERCEIVED TECHNOLOGICAL CHARACTERISTICS AND REAL OPTIONS IN CLOUD COMPUTING ADOPTION" (2010). ICIS 2010 Proceedings. 24. Available online: https://aisel.aisnet.org/icis2010_submissions/24 (accessed on 30 May 2020).

140. Hossain, M.A.; Quaddus, M. Radio frequency identification (RFID) adoption: A cross-sectional comparison of voluntary and mandatory contexts. Inf. Syst. Front. 2015, 17, 1057-1076. [CrossRef]

141. Asadi, S.; Nilashi, M.; Safaei, M.; Abdullah, R.; Saeed, F.; Yadegaridehkordi, E.; Samad, S. Investigating factors influencing decision-makers' intention to adopt Green IT in Malaysian manufacturing industry. Resour. Conserv. Recycl. 2019, 148, 36-54. [CrossRef]

142. Bunduchi, R.; Weisshaar, C.; Smart, A.U. Mapping the benefits and costs associated with process innovation: The case of RFID adoption. Technovation 2011, 31, 505-521. [CrossRef]

143. Gagnon, Y.-C.; Toulouse, J.-M. The behavior of business managers when adopting new technologies. Technol. Forecast. Soc. Chang. 1996, 52, 59-74. [CrossRef]

144. Lal, P.; Bharadwaj, S.S. Understanding the impact of cloud-based services adoption on organizational flexibility: An exploratory study. J. Enterp. Inf. Manag. 2016, 29, 566-588. [CrossRef]

145. Kwon, T.H.; Zmud, R.W. Unifying the fragmented models of information systems implementation. In Critical Issues in Information Systems Research; John Wiley \& Sons, Inc.: Hoboken, NJ, USA, 1987.

146. Mata, F.J.; Fuerst, W.L.; Barney, J.B. Information technology and sustained competitive advantage: A resource-based analysis. Mis Q. 1995, 487-505. [CrossRef]

147. Mokhtar, S.A.; Ali, S.H.S.; Al-Sharafi, A.; Al-Sharafi, A. Organizational Factors in the Adoption of Cloud Computing in E-learning. In Proceedings of the 3rd International Conference on Advanced Computer Science Applications and Technologies Acsat, Amman, Jordan, 26 December 2014; pp. 188-191.

148. Albalawi, M.S. Critical Factors Related to the Implementation of Web-Based Instruction by Higher-Education Faculty at Three Universities in the Kingdom of Saudi Arabia. Ph.D. Thesis, University of West Florida, Pensacola, FL, USA, 2007.

149. Mansour, A.J. The Adoption of Cloud Computing Technology in Higher Education Institutions: Concerns and Challenges (Case Study on Islamic University of Gaza'iug'), IUG dissertation. 2013. Available online: http://hdl.handle.net/20.500.12358/17670 (accessed on 30 May 2020).

150. Sathyanarayana, T.; Sheela, L.M.I. Data security in cloud computing. In Proceedings of the 2013 International Conference on Green Computing, Communication and Conservation of Energy (ICGCE), Chennai, India, 12-14 December 2013; IEEE: Piscataway, NJ, USA, 2013.

151. Subashini, S.; Kavitha, V. A survey on security issues in service delivery models of cloud computing. J. Netw. Comput. Appl. 2011, 34,1-11. [CrossRef]

152. Wheeler, B.; Waggener, S. Above-campus services: Shaping the promise of cloud computing for higher education. Educ. Rev. 2009, 44, 52-67.

153. Weber, A.S. Cloud computing in education in the Middle East and North Africa (MENA) Region: Can barriers be overcome? In Conference Proceedings of «ELearning and Software for Education» (eLSE); Carol, I., Ed.; National Defence University Publishing House: Bucharest, Romania, 2011.

154. Ciganek, A.P.; Haseman, W.; Ramamurthy, K. Time to decision: The drivers of innovation adoption decisions. Enterp. Inf. Syst. 2014, 8, 279-308. [CrossRef]

155. Yoon, T.E.; George, J.F. Why aren't organizations adopting virtual worlds? Comput. Hum. Behav. 2013, 29, 772-790. [CrossRef] 
156. Wymer, S.A.; Regan, E.A. Factors influencing e-commerce adoption and use by small and medium businesses. Electron. Mark. 2005, 15, 438-453. [CrossRef]

157. Rousseau, D.M. Issues of level in organizational research: Multi-level and cross-level perspectives. Res. Organ. Behav. 1985, 7, 1-37.

158. Chau, P.Y.; Tam, K.Y. Factors Affecting the Adoption of Open Systems: An Exploratory Study. MIS Q. 1997, 21, 1-24. [CrossRef]

159. Kuan, K.K.; Chau, P.Y. A perception-based model for EDI adoption in small businesses using a technology-organization-environment framework. Inf. Manag. 2001, 38, 507-521. [CrossRef]

160. Ghobakhloo, M.; Arias-Aranda, D.; Benitez-Amado, J. Adoption of e-commerce applications in SMEs. Ind. Manag. Data Syst. 2011, 111, 1238-1269. [CrossRef]

161. Thiesse, F.; Staake, T.; Schmitt, P.; Fleisch, E. The rise of the "next-generation bar code": An international RFID adoption study. Supply Chain Manag. Int. J. 2011, 16, 328-345. [CrossRef]

162. Klein, R. Assimilation of Internet-based purchasing applications within medical practices. Inf. Manag. 2012, 49, 135-141. [CrossRef]

163. Lin, A.; Chen, N.-C. Cloud computing as an innovation: Percepetion, attitude, and adoption. Int. J. Inf. Manag. 2012, 32, 533-540. [CrossRef]

164. Nkhoma, M.Z.; Dang, D.P.; De Souza-Daw, A. Contributing factors of cloud computing adoption: A technology-organisation-environment framework approach. In Proceedings of the European Conference on Information Management \& Evaluation, Gdansk, Poland, 12-13 September 2013.

165. Alshamaila, Y.; Papagiannidis, S.; Li, F. Cloud computing adoption by SMEs in the north east of England: A multi-perspective framework. J. Enterp. Inf. Manag. 2013, 26, 250-275. [CrossRef]

166. Wu, Y.; Cegielski, C.G.; Cegielski, B.T.; Hall, D.J. Cloud computing in support of supply chain information system infrastructure: Understanding when to go to the cloud. J. Supply Chain Manag. 2013, 49, $25-41$. [CrossRef]

167. Cheng, X.; Bounfour, A. The determinants of Cloud Computing Adoption by Large European Firms. Inf. Syst. Chang. Econ. Soc. 2015, 50.

168. Salum, K.H.; Rozan, M.Z.A. Conceptual model for cloud erp adoption for smes. J. Theor. Appl. Inf. Technol. 2017, 95, 743.

169. Chan, F.T.S.; Chong, A.Y.L. A SEM-neural network approach for understanding determinants of interorganizational system standard adoption and performances. Decis. Support Syst. 2012, 54, 621-630. [CrossRef]

170. Venkatesh, V.; Goyal, S. Expectation Disconfirmation and Technology Adoption: Polynomial Modeling and Response Surface Analysis. Mis Q. 2010, 34, 281-303. [CrossRef]

171. Joshi, R.; Yadav, R. An integrated SEM neural network approach to study effectiveness of brand extension in Indian FMCG industry. Bus. Perspect. Res. 2018, 6, 113-128.

172. Ahani, A.; Rahim, N.Z.A.; Nilashi, M. Forecasting social CRM adoption in SMEs: A combined SEM-neural network method. Comput. Hum. Behav. 2017, 75, 560-578. [CrossRef]

173. Chong, A.Y.-L.; Bai, R. Predicting open IOS adoption in SMEs: An integrated SEM-neural network approach. Expert Syst. Appl. 2014, 41, 221-229. [CrossRef]

174. Daniel, J. Sampling Essentials: Practical Guidelines for Making Sampling Choices; Sage: Thousand Oaks, CA, USA, 2011.

175. Kotrlik, J.; Higgins, C. Organizational research: Determining appropriate sample size in survey research appropriate sample size in survey research. Inf. Technol. Learn. Perform. J. 2001, 19, 43.

176. Sibona, C.; Walczak, S. Purposive Sampling on Twitter: A Case Study. In Proceedings of the 2012 45th Hawaii International Conference on System Sciences, Maui, HI, USA, 4-7 January 2012.

177. Hertzog, M.A. Considerations in determining sample size for pilot studies. Res. Nurs. Health 2008, 31, 180-191. [CrossRef]

178. Saunders, M.N. Research Methods for Business Students; Pearson Education India: Upper Saddle River, NJ, USA, 2011.

179. Sekaran, U.; Bougie, R. Research Methods for Business, A Skill Building Approach; John Willey \& Sons, Inc.: New York, NY, USA, 2003.

180. Tellis, W.M. Introduction to Case Study. The Qualitative Report, 3, 1-14. 1997. Available online: https: //nsuworks.nova.edu/tqr/vol3/iss2/4 (accessed on 30 May 2020). 
181. Whitehead, A.L.; Julious, A.S.; Cooper, C.L.; Campbell, M.J. Estimating the sample size for a pilot randomised trial to minimise the overall trial sample size for the external pilot and main trial for a continuous outcome variable. Stat. Methods Med Res. 2016, 25, 1057-1073. [CrossRef]

182. Straub, D.; Boudreau, M.-C.; Gefen, D. Validation guidelines for IS positivist research. Commun. Assoc. Inf. Syst. 2004, 13, 24. [CrossRef]

183. Chin, W.W.; Marcolin, B.L.; Newsted, P.R. A partial least squares latent variable modeling approach for measuring interaction effects: Results from a Monte Carlo simulation study and an electronic-mail emotion/adoption study. Inf. Syst. Res. 2003, 14, 189-217. [CrossRef]

184. Hulland, J. Use of partial least squares (PLS) in strategic management research: A review of four recent studies. Strateg. Manag. J. 1999, 20, 195-204. [CrossRef]

185. Gefen, D.; Rigdon, E.E.; Straub, D. Editor's Comments: An Update and Extension to SEM Guidelines for Administrative and Social Science Research. MIS Q. 2011, 35, iii-xiv. [CrossRef]

186. Chin, W.W. How to write up and report PLS analyses. In Handbook of Partial Least Squares; Springer: Berlin/Heidelberg, Germany, 2010; pp. 655-690.

187. Ainuddin, R.A.; Beamish, P.W.; Hulland, J.S.; Rouse, M.J. Resource attributes and firm performance in international joint ventures. J. World Bus. 2007, 42, 47-60. [CrossRef]

188. Henseler, J.; Ringle, C.M.; Sinkovics, R.R. The use of partial least squares path modeling in international marketing. In New Challenges to International Marketing; Emerald Group Publishing Limited: Bradford, UK, 2009; pp. 277-319.

189. Urbach, N.; Ahlemann, F. Structural equation modeling in information systems research using partial least squares. J. Inf. Technol. Theory Appl. 2010, 11, 5-40.

190. Fornell, C.; Larcker, D.F. Structural Equation Models with Unobservable Variables and Measurement Error: Algebra and Statistics. J. Mark. Res. 1981, 18, 382-388. [CrossRef]

191. Liébana-Cabanillas, F.; Marinković, V.; Kalinić, Z. A SEM-neural network approach for predicting antecedents of m-commerce acceptance. Int. J. Inf. Manag. 2017, 37, 14-24. [CrossRef]

192. El-Amir, H.; Hamdy, M. A Tour through the Deep Learning Pipeline. In Deep Learning Pipeline; Springer: Berlin/Heidelberg, Germany, 2020; pp. 57-84.

193. Jaafar, K.; Ismail, N.; Tajjudin, M.; Adnan, R.; Rahiman, M.H.F. Artificial Neural Networks for Water Level Prediction Based on Z-Score Technique in Kelantan River. Int. J. Electr. Electron. Syst. Res. 2018, 13.

194. Wang, Y.-M.; Elhag, T.M. A comparison of neural network, evidential reasoning and multiple regression analysis in modelling bridge risks. Expert Syst. Appl. 2007, 32, 336-348. [CrossRef]

195. Asadi, S.; Abdullah, R.; Jusoh, Y.Y. An Integrated SEM-Neural Network for Predicting and Understanding the Determining Factor for Institutional Repositories Adoption. In Proceedings of the SAI Intelligent Systems Conference, London, UK, 5-6 September 2019; Springer: Cham, Switzerland, 2019.

196. Sabi, H.M.; Uzoka, F.-M.E.; Mlay, S.V. Staff perception towards cloud computing adoption at universities in a developing country. Educ. Inf. Technol. 2018, 23, 1-24. [CrossRef]

197. Hair, J.F.; Ringle, C.M.; Sarstedt, M. Partial least squares structural equation modeling: Rigorous applications, better results and higher acceptance. Long Range Plan. 2013, 46, 1-12. [CrossRef]

198. Qasem, Y.A.; Abdullah, R.; Jusoh, Y.; Atan, R. Cloud-Based Education As a Service (CEAAS) System Requirements Specification Model of Higher Education Institutions in Industrial Revolution 4.0. Int. J. Adv. Technol. Eng. Explor. 2019, 8, 1382-1386.

199. Nuseibeh, H. Adoption of Cloud Computing in Organizations. AMCIS 2011 Proceedings-All Submissions. 372. 2011. Available online: http://aisel.aisnet.org/amcis2011_submissions/372 (accessed on 30 May 2020).

200. Bhattacherjee, A. Understanding Information Systems Continuance: An Expectation-Confirmation Model. MIS Q. 2001, 25, 351-370. [CrossRef]

201. Morgan, L.; Conboy, K. Factors affecting the adoption of cloud computing: An exploratory study. In Proceedings of the ECIS 21st European Conference on Information Systems 2013, Utrecht, The Netherlands, 5-8 June 2013; pp. 1-12. Available online: http://hdl.handle.net/10344/3209 (accessed on 30 May 2020).

202. Rieger, P.; Gewald, H.; Schumacher, B. Cloud-computing in banking influential factors, benefits and risks from a decision maker's perspective. In Proceedings of the AMCIS 2013, Chicago, IL, USA, 15-17 August 2013; pp. 1-12.

203. Lian, J.-W.; Yen, D.C.; Wang, Y.-T. An exploratory study to understand the critical factors affecting the decision to adopt cloud computing in Taiwan hospital. Int. J. Inf. Manag. 2014, 34, 28-36. [CrossRef] 
204. Benlian, A.; Hess, T. Opportunities and risks of software-as-a-service: Findings from a survey of IT executives. Decis. Support Syst. 2011, 52, 232-246. [CrossRef]

205. Luo, X.; Gurung, A.; Shim, J.P. Understanding the determinants of user acceptance of enterprise instant messaging: An empirical study. J. Organ. Comput. Electron. Commer. 2010, 20, 155-181. [CrossRef]

206. Wu, W.-W. Mining significant factors affecting the adoption of SaaS using the rough set approach. J. Syst. Softw. 2011, 84, 435-441. [CrossRef]

207. Cervone, H.F. An overview of virtual and cloud computing. OCLC Syst. Serv. Int. Digit. Libr. Perspect. 2010, 26, 162-165. [CrossRef]

208. Marston, S.; Li, Z.; Bandyopadhyay, S.; Zhang, J.; Ghalsasi, A. Cloud computing-The business perspective. Decis. Support Syst. 2011, 51, 176-189. [CrossRef]

209. Lee, S.; Kim, K.-J. Factors affecting the implementation success of Internet-based information systems. Comput. Hum. Behav. 2007, 23, 1853-1880. [CrossRef]

210. Frambach, R.T.; Barkema, H.G.; Nooteboom, B.; Wedel, M. Adoption of a service innovation in the business market: An empirical test of supply-side variables. J. Bus. Res. 1998, 41, 161-174. [CrossRef]

211. Yap, C.-S.; Thong, J.Y.; Raman, K. Effect of government incentives on computerisation in small business. Eur. J. Inf. Syst. 1994, 3, 191-206. [CrossRef]

(C) 2020 by the authors. Licensee MDPI, Basel, Switzerland. This article is an open access article distributed under the terms and conditions of the Creative Commons Attribution (CC BY) license (http://creativecommons.org/licenses/by/4.0/). 